\title{
Synthesizing Related Rules from Statutes and Cases for Legal Expert Systems
}

\author{
LAYMAN E. ALLEN, SALLYANNE PAYTON \\ and CHARLES S. SAXON
}

Abstract. Different legal expert systems may be incompatible with each other: $A$ user in characterizing the same situation by answering the questions presented in a consultation can be led to contradictory inferences. Such systems can be "synthesized" to help users avoid such contradictions by alerting them that other relevant systems are available to be consulted as they are responding to questions. An example of potentially incompatible, related legal expert systems is presented here - ones for the New Jersey murder statute and the celebrated Quinlan case, along with one way of synthesizing them to avoid such incompatibility.

\section{Introduction}

A crucial step in both the initial building of, as well as the updating of rulebased legal expert systems, is determining which legal rules are to be embodied in the system. This process of determining the rules to be embodied involves two distinct substeps: (1) deciding whether a candidate legal rule is actually a legal rule in the jurisdiction to which the expert system applies, and (2) selecting from: the actual legal rules in that jurisdiction, the ones that are to be embodied in the expert system. The rules selected will determine the scope and completeness of the system. The existence in the federal system of the United States of multiple state systems, coupled with a national legal system makes deciding which legal rules are applicable in a given jurisdiction both complicated and uncertain. To the extent that the grand metaphor of the legal system as a "seamless web" mirrors legal reality, such selection is inevitably arbitrary and results in an expert system that is incomplete - but such selection is a necessary concession for building practical expert systems for specific parts of the total legal system.

Some of the problems of designing and updating a legal expert system (hereafter, 
"LES") are exemplified in this article by a small LES that deals with criminal homicide in the State of New Jersey. Rules from the New Jersey Code of Criminal Justice are embodied in this LES. A second LES is built from the rules set forth in the order for declaratory relief in the opinion of the New Jersey Supreme Court in In the Matter of Karen Quinlan, an Alleged Incompetent 70 N.J. 10, 355 A.2d 647,79 ALR 3d 205 (1976).

The opinion of the New Jersey Supreme Court in the Quinlan case drew upon some additional rules articulated by the United States Supreme Court in interpreting the United States Constitution which bear on how the Quinlan rules are to be appropriately integrated or synthesized with the other New Jersey legal rules. The need for such synthesis is dramatically illustrated by the contradictory inferences that are drawn when a given hypothetical situation is analyzed by each LES separately. Clearly, some means of resolving this incompatibility is needed. One alternative is an integration of the rules that comprise the two systems to form a combined LES. Another alternative, and the one pursued in greater detail in this paper, is to synthesize related expert systems by providing assistance to coordinate their use to help users avoid the potential incompatibilities. The discussion that follows is motivated by the need to develop a procedure for synthesizing related rules for legal expert systems.

\section{Expert System of the New Jersey Rules of Criminal Homicide}

Title 2C, Chapter 11 of the New Jersey Revised Statutes deals with criminal homicide. The first five sections of Chapter 11 define four forms of criminal homicide: murder, aggravated manslaughter, manslaughter, and death by auto. The sixth section defines another crime, aiding suicide, which is not a criminal homicide. A legal expert system called NJ2C-11 has been constructed from these six sections of Chapter $11 .{ }^{1}$ The Present Version of the parts of these six sections that are embodied in NJ2C-11 are set forth in Appendix A.

These six sections have been transformed into Clear Normalized Form, which is also set forth in Appendix A. This normalized interpretation of Chapter 11 of the New Jersey Code of Criminal Justice is automatically generated when an appropriate input file is used with the NORMALIZER software (Allen and Saxon 1985). When this same input file is used with the AUTOPRO software (Allen and Saxon 1988a, 1988b, 1988c, 1988d, Allen and Stipanovic 1988) the Prolog code for the NJ2C-11 LES is automatically generated. NORMALIZER also generates another normalized representation of Chapter 11 called the Clear Mnemonic Arrow Diagram. Both of these normalized versions express the rules embodied in the LES in a manner that enables the lawyer expert to easily check that they correspond with his or her expert opinion about how the provisions

${ }^{1}$ It should be noted, however, that $\mathrm{NJ} 2 \mathrm{C}-11$ does not include the provisions expressed in subsections $2 C-11-3(b-g)$ that deal with sentencing of those convicted of murder. NJ2C-11 also omits section 2C-11-2.1, dealing with Elapse of time between assault and death, prosecution for criminal homicide. 
of the New Jersey Code of Criminal Justice are to be interpreted. The input file for the two computer programs and the Clear Mnemonic Arrow Diagram of the interpretation of Chapter 11 are also included in Appendix A. ${ }^{2}$

Section 11-3 of the New Jersey Code of Criminal Justice provides, among other things, (1) that a person knowingly causing the death of another human being is guilty of criminal homicide, and (2) that if the criminal homicide is not done in the heat of passion resulting from a reasonable provocation, it constitutes murder. Consider how the following hypothetical situation would be analyzed by using the NJ2C-11 LES or the normalized versions of the interpretation of Chapter 11 that has been embodied in NJ2C-11.

A father sought and was appointed guardian of the person and property of his 21-year old daughter who was in a persistent vegetative state. He also sought and obtained from the court the express power of authorizing the discontinuance of all extraordinary procedures for sustaining the daughter's vital processes, which were then being sustained by a mechanical respirator. The court order included permission to have the respirator disconnected. The daughter's attending physicians had advised the father and the rest of the family that there was no chance that the daughter would ever emerge from her comatose state and had recommended that the mechanical respirator be disconnected. After obtaining authority from the court to discontinue extraordinary procedures, the father along with the rest of the family (1) concurred with the physicians' judgment that the daughter would never recover and that the respirator should be disconnected, and (2) authorized the attending physicians to consult with the hospital Ethics Committee about disconnecting it. After the Ethics Committee agreed with the physicians' prognosis, the physicians disconnected the respirator, and the daughter died within an hour.

When the facts of this case were brought to the attention of the prosecutor, she consulted the NJ2C-11 LES on criminal homicide about the case and was advised that the physicians were guilty of the criminal homicide of murder under 2C-11-3 of the New Jersey Code of Criminal Justice. The record of her consultation with NJ2C-11 is included in Appendix A.

\section{Background to In re Quinlan}

In re Quinlan (Quinlan case 1976) owes its prominence to the fact that it changed the nature of legal analysis of situations involving the termination of treatment on permanently unconscious or terminally ill patients. Prior to Quinlan the termination of treatment on a patient under circumstances where that patient was likely to die without the assistance of the treatment so terminated would have been characterized by well-socialized lawyers and judges as homicide in

${ }^{2}$ Copies of the NORMALIZER software and of the AUTOPRO software are available to those researchers and practicing lawyers who wish to explore the use of it. Requests should be addressed to: Layman E. Allen, Law School, University of Michigan, Ann Arbor, MI 48109-1215. 
every state. ${ }^{3}$ The New Jersey homicide statute in force in 1975 was typical of the state of the law; it provided:

\section{A:113-1. Murder}

If any person, in committing or attempting to commit arson, burglary, kidnapping, rape, robbery, sodomy or any unlawful act against the peace of this state, of which the probable consequences may be bloodshed, kills another, or if the death of any one ensues from the committing or attempting to commit any such crime or act; or if any person kills a judge, magistrate, sheriff, coroner, constable or other officer or justice, either civil or criminal, of this state, or a marshal or other officer of justice, either civil or criminal, of the United States, in the execution of his office or duty, or kills any of his assistants, whether specially called to his aid or not, endeavoring to preserve the peace or apprehend a criminal, knowing the authority of such assistant, or kills a private person endeavoring to suppress an affray, or to apprehend a criminal, knowing the intention with which such private person interposes, then such person so killing is guilty of murder. ${ }^{4}$

Reading this statute, the general counsel to St. Clare Hospital in New Jersey advised the hospital and the physicians that terminating treatment on this patient at the request of her family would qualify as homicide and would make them vulnerable to prosecution by the state. On this point, both the Quinlans' own lawyer and the prosecuting authorities of the State of New Jersey agreed. No one argued that the New Jersey homicide statute did not mean what it said and say what it meant. The question was not whether the homicide statute was being read correctly but whether there was another source of law that might govern the situation and override the homicide statute.

In re Quinlan is thus a case in which the deductive application of a rule of law to a particular case was uncontroverted. If the only question had been whether termination of treatment constituted homicide within the New Jersey statute, Quinlan would have been an easy case. What made it complicated and interesting is that the Quinlans' lawyer argued, and the New Jersey Supreme Court agreed, that there were other sources of law superior to the New Jersey homicide statute that could be read to privilege the termination of treatment on Karen and to disable the state from prosecuting for homicide those persons who might participate in terminating treatment pursuant to the procedures set forth in the opinion. In re Quinlan held that the permanently unconscious patient in a persistent vegetative state has a personal privacy interest, protected under

${ }^{3}$ The homicide characterization furnished the basis for popular argument over whether such termination, when done out of sympathy for the patient, might be characterized as "euthanasia" and be under some circumstances allowed; however, there is no "euthanasia" exception to the homicide statutes. An intentional killing of a human being is homicide regardless of the motive of the killer. Whether a prosecutor would actually have prosecuted, or a jury have convicted, a physician who terminated treatment on a patient in Karen Quinlan's situation is of course doubtful; however, a competent lawyer would have advised medical professionals that there would be some risk of prosecution and some chance, however remote, of conviction.

4 This provision has been replaced by the New Jersey Code of Criminal Justice, Chapter 11, Section 3. The new provision is part of the basis for the legal expert system discussed in Section 2 and illustrated in Appendices $A$ and $C$. 
New Jersey law, the New Jersey constitution, and the United States Constitution, to refuse medical treatment consisting of life-support being provided for the sole purpose of maintaining the patient in the vegetative state, where the prognosis is that the patient will not return to a cognitive, sapient state. The patient's interest may be protected by the guardian, acting in accordance with procedures set forth in the Quinlan case designed to ensure that the decision is made in accordance with appropriate medical standards and in a manner not inconsistent with the privilege of medical professionals not to be commanded by laypersons to make treatment decisions that are contrary to their ethical views.

The Quinlan case is an unusually interesting and instructive instance of a case in which a court is faced with a problem of selecting which legal rules and principles to apply in the circumstances of the case before it. It must be remembered that there is no "case" unless lawyers are willing to present to the court conflicting versions of the law or the facts of the matter in controversy. In the Quinlan situation there was no significant controversy over the facts; consequently, if the Quinlan family had simply acquiesced in the version of the law articulated by the hospital's attorney, there would have been no case. However, the Quinlans believed that as the family of the patient they ought to have the power to decide when to terminate use of the respirator and the right that the state not interfere with the exercise of that power, and were convinced that the law in fact would uphold their position once the question was posed squarely to the court. It was only because they sought out a different lawyer who brought strikingly different intellectual resources to the argument of the case that the Quinlans were able to present to the court an alternative view of what the law ought to be. In the end, the Quinlans' view of what the law would be declared to be, was largely prophetic: The New Jersey Supreme Court gave them nearly the full measure of the relief that they sought.

If the Quinlans and their lawyer prevailed because they correctly anticipated that the federal constitutional privacy interests and the idea of personal autonomy in medical decision-making would be invoked by the New Jersey Supreme Court to limit the scope of the New Jersey homicide statute, does that mean that the lawyer for the hospital was wrong? Clearly not: the position that he took was in accordance with "the law" as any good lawyer would have understood it. On the other hand, good lawyers would also have seen, and did see, the intellectual force of the evolving jurisprudence of privacy and individual autonomy. Most of these strains of legal thinking were not yet part of "the law," in the narrow sense, of patient care prior to In re Quinlan, but were plainly positioned to be deployed in this context. How would lawyers have known that? This issue poses the most difficult - and perhaps insoluble - problem for the developer of legal expert systems: How does a good lawyer know what sources of law might be available to be deployed in argument in a particular case? Quinlan is, of course, an unusual case in that it is a paradigm-shifting case and therefore is unusually dramatic in the way in which it repositions the legal 
argument with respect to the entire universe of medical decision-making. However, Quinlan is only an extreme example of the kind of reasoning that courts and lawyers do every day: Legal reasoning is as much a matter of selecting the rules to apply, as it is of interpreting rules by deciding what characterizations should be regarded as controlling, and "applying" the rules thus selected and interpreted deductively to particular fact situations. Courts of course have the authority to decide which rules and principles will be invoked or deployed; the primary role of lawyers in litigation is to present their clients' stories to the courts in the most sympathetic light and to propose to the court rules and principles advantageous to their clients for deductive "application" in the particular case. The good lawyer must be aware of the range of rules and principles that might be proposed by competent practitioners, of the arguments that must be met. Good lawyers typically, not atypically, reach outside of the apparent legal domain, the most obvious "subject matter," for principles and analogies. In fact, the hallmark of the best lawyers is their peripheral vision, their ability to see trouble or opportunity at the margin of the terrain. Is it remotely possible that a computerized expert system could either emulate the performance of those lawyers, or point lawyers in the right direction? Can a legal expert system, in other words, help good lawyers become better ones, or are the requirements of computability such that the real essence of the legal art cannot be captured? In order to approach that question it is necessary to discover how lawyers recognize the resources that are available to them in legal reasoning. We shall approach the reasoning in In re Quinlan with that task in mind.

\section{A. The Legal and Factual Beginning Position}

Let us begin at the beginning. What were the powers and rights of patients prior to Quinlan, and what were the powers and duties of families and medical professionals? Karen was an adult, 21 years old at the time when she was admitted to the hospital. Ordinarily, a patient, if competent, has the legal power to consent to treatment or to withhold consent, and a doctor has a duty not to administer treatment without the informed consent of the patient; the corollary is that the patient has a right that the doctor not administer treatment unless the patient has consented. However, where the patient is unable to give informed consent but is in a condition in which any reasonable person would consent, e.g., in an emergency or where the patient is unconscious or otherwise temporarily incapacitated, the patient's consent to treatment that is medically necessary and within the standard of care is implied in law. Karen Quinlan, having been admitted to the hospital as an emergency patient in a comatose state, was therefore presumed to have consented to treatment that was within the standard of medical care, which of course included the use of life-support technology where medically indicated.

As the law stood in 1975, it was not clear that Karen would have had the legal power to refuse to be placed on the respirator had she been sufficiently 
conscious and competent to give or withhold informed consent upon her admission to the hospital. It was generally true that competent patients had the power to withhold consent to treatment. However, where they attempted to exercise the power under circumstances in which they might die if the treatment were not rendered, the courts tended to exercise their parens patriae powers in order to compel treatment (ALR 1964). The typical situation would be that of a terminally ill patient, for example, a cancer patient undergoing painful and protracted treatment such as radical surgery; the usual procedure when such a patient attempted to refuse treatment was for the hospital to petition the court for (a) a declaration that the patient was behaving irrationally and was mentally incompetent to make medical decisions and (b) the appointment of a guardian to consent to treatment. ${ }^{5}$ The patient's desire to die rather than to undergo treatment would be regarded as evidence of the patient's mental incompetence to make medical decisions in a rational manner. There had been several federal constitutional cases involving Jehovah's Witnesses who claimed a right to forgo receiving blood transfusions even though they might die as a result of the refusal; in the context of these cases the courts had articulated the proposition that the state had an interest in the preservation of life even over the patient's religious objection to treatment, where the state's interest in preserving life, preventing suicide, protecting the interests of innocent third parties (e.g., children), and protecting the ethical integrity of the medical profession outweighed the patient's interest in allowing the life to be terminated. Using this balancing test, those courts that had published decisions in the Jehovah's Witnesses cases had generally ordered Jehovah's Witnesses to undergo blood transfusions rather than die (Application of President \& Directors of Georgetown College, Inc., 118 U.S. App. D.C. 80, 330 F2d 1000, 9 ALR 3d 1367 (D.C. Cir. 1964), cert. den., 337 U.S. 978, 84 S.Ct. 1883, 12 L.Ed. 2 d 746 (1964)). It was against this essential background that the Quinlan case arose. The rights of even competent patients were in doubt.

This was not to say that actual refusals of treatment, and actual decisions on the part of medical professionals to terminate treatment, were not commonplace by 1975 . The dissemination of medical technology through the construction of modern hospitals had meant that by the mid-1970s intensive care units and life-support technologies had become widely available. Since the dominant ethic of the medical profession is to treat aggressively even in doubtful cases, it was inevitable that these technologies would be used on a wider range of patients than those who could be restored effectively to a satisfactory condition, and therefore inevitable that the discontinuance of life supports on some patients would be viewed as medically appropriate. The current state of medical practice was, in other words, that acts that the law characterized as homicide were

${ }^{5}$ See N.J.Stat.Ann. 3B:12-36 (1983) and its predecessor, R.S. 3:21-3; 3:21-4, amended by L.1938, c. 133, p. $285, \S 1$. If a person has been adjudged a mental incompetent and a guardian of his person appointed, the court has, under New Jersey law, "full authority over the ward's person and all matters relating thereto." 
being committed routinely in major hospitals as a matter of ordinary medical decision-making. In addition, there were a number of patients in the situation of Karen Ann Quinlan: patients who had been rendered permanently unconscious by some adverse acute episode but whose brain stems were intact and who might be kept in a vegetative state for a very long time without hope of recovering cognitive function. Since these patients were typically capable of maintaining circulatory and respiratory functions on their own, the usual course of practice in major hospitals was to wean them from the life-support systems when their condition had stabilized and to transfer them to skilled nursing facilities. Karen's physicians were persuaded, however, that she could not be weaned, so the case was tried on the theory that Quinlan herself fit into the category of patients on whom termination of life-support would likely mean death (Quinlan case 1976).

The New Jersey courts therefore faced a conceptual problem that was also an intensely practical problem. Medical professionals were inclined, in the exercise of their professional judgment, to commit acts that technically constituted homicide. It was likely that they were aware of the existence of the homicide statutes and were in some instances influenced by the risk of prosecution to make treatment decisions that they would not otherwise have viewed as medically appropriate. The homicide laws did not, however, quite fit the situation of medical professionals and their patients in the modern hospital. The medical professionals came under an obligation not to cease treatment only because they had commenced treatment in the first place with the patient's consent, express or implied, in an effort to save the patient's life. Having assumed the professional relationship, they had a duty to provide treatment within the standard of care, and had a further duty not to abandon the patient in a situation in which the patient could not survive without their ministrations. In addition, it seemed, the law imposed upon them an obligation to protect the patient's life by continuing life-sustaining treatment once it had been commenced. All of their duty and privilege to treat the patient depended, however, in the first instance on the patient's having consented to be treated. Indeed, the consent basis of the relationship between doctor and patient is so central that when a guardian is appointed to make medical decisions for a patient the guardian is authorized to consent to treatment (N.J.S.A. 3A:22-1 Exercising power of consent for mental incompetent; order, effect). Because the entire doctor-patient relationship pivots on the patient's consent, so must the duties that undergird the obligation to continue treatment, and so must also the application of the homicide statute to any decision to terminate treatment.

It was the law that determined the powers of the patient, or the patient's guardian, to consent to treatment or to withhold consent. It was therefore the law that would determine when treatment might be terminated. However, the question for the New Jersey Supreme Court was what the law ought to be in the case of a permanently unconscious patient. Plainly the notion, implicit in the homicide statute, that the medical professionals must do nothing that would 
hasten the patient's death was neither realistic as a practical matter nor supported by the medical, religious or ethical authorities that had focused their attention on the problem. Even Pope Pius XII, speaking out of the Catholic Church's principled opposition to "euthanasia" had said some 18 years before the Quinlan matter arose that a family had a right to refuse to consent to the use of modern respiratory apparatus in cases of "deep unconsciousness" where the case was "completely hopeless" and the use of the apparatus might be deemed "extraordinary." The Pope's position was that the physicians had no right to insist on treatment over the family's opposition, and that the interruption of attempts at resuscitation is not euthanasia, even when as a physical matter the interruption of such efforts would cause the arrest of circulation. Pius XII had applied to this problem the principle of "double effect." (The "allocutio" to anesthesiologists delivered by Pius XII on November 24, 1957 is quoted in Quinlan 1976, 31.)

There was and is no legal concept within homicide law that functions in the same manner as the Catholic principle of "double effect." The Catholic principle is that an act that is physically the cause of death may not be morally the cause of death because of the actor's admirable motivation in committing the act that foreseeably will lead to the death. The law of homicide, on the other hand, does not contain an exception for well-motivated killings, or for killings that are incidental to good deeds. Good lawyers conversant with the law of homicide would never have doubted that the disconnecting of the respirator would "cause," in both the physical and legal senses, whatever cessation of respiration might occur in the patient thereafter.

On the other hand, notions of causation within the law are bound up with concepts of responsibility, and legal responsibility in both civil tort and criminal law depends on the proposition, not only that the actor physically caused an event complained of, but that the actor had a duty not to cause the event. If the medical professionals were to be vulnerable to prosecution for ceasing to treat Karen, that vulnerability must derive from their having a duty to treat. Since their duty derived in the first instance from the patient's consent, a holding by the court that the patient could exercise the power to withdraw consent would necessarily imply that the medical professionals would, if the patient exercised that power, cease to have a duty to treat, and would even have a duty not to treat. A holding in favor of the Quinlans on the question of their power to withdraw consent to treatment would necessarily, then, influence the reading of the homicide statute: It would be inconsistent and incoherent for the law to acknowledge the physicians' duty to cease treatment and at the same time make them liable to prosecution for homicide for having caused the consequences of cessation. It was therefore not so obvious as it might first have appeared that the homicide statute applied to instances of terminating treatment on a permanently unconscious patient: That reading of the homicide statute presupposed that the physicians had a duty to continue treatment, and it was precisely that idea that the Quinlans challenged by claiming that they or Karen had a constitutionally protected power to withdraw consent. 
The Quinlans could only prevail in this line of reasoning if the court were to agree that their interests or Karen's outweighed the interest of the state in the preservation of life. The state's interest in this case was both general and specific: The general policy against the taking of life is expressed in the homicide statute, and, in addition, the state had a specific parens patriae responsibility toward Karen herself because she was legally incompetent. Karen Quinlan was technically a ward of the state and therefore was within the equity jurisdiction of the probate court. The central conceptual problems in the case, therefore, were (a) what was the state's parens patriae responsibility toward a patient in Karen's condition; and (b) was Joseph Quinlan an appropriate person to exercise this responsibility by delegation from the court? The New Jersey Supreme Court cited with approval the lower court judge's formulation of the powers of the state exercising parens patriae power:

As part of the inherent power of equity, a Court of Equity has full and complete jurisdiction over the persons of those who labor under any legal disability... The Court's action in such a case is not limited by any narrow bounds, but it is empowered to stretch forth its arm in whatever direction its aid and protection may be needed. ...(137 N.J.Super, at 254, quoted in Quinlan case 1976, 44)

These powers are to be exercised for the benefit of the ward ${ }^{6}$ the usual formulation of the standard that is to govern their exercise is that the court is to act in the "best interests" of the ward. It is important to keep this point in mind, because it is crucial to realize in thinking about the Quinlan case that the powers of the guardian appointed by the court are delegated from the court, acting as the state in its parens patriae capacity, to the guardian. That is, the guardian is the agent of the state and is bound by the same duties that bind the state itself. The guardian is authorized to act for the benefit of the patient, not for his own private interest. Moreover, the court has an obligation to select only appropriate guardians, since they are to make the judgments that constitute the exercise of the state's parens patriae power. In the exercise of this equity probate jurisdiction, which is fundamentally an administrative function rather than a dispute resolution function, the courts formulate and act upon the state's ethical obligations towards its citizens who labor under legal disabilities; the foremost duty of the state toward its wards is to protect them when they are unable to do so for themselves. The Quinlan situation raised the possibility that the state's duties in its parens patriae role vis-à-vis particular permanently unconscious patients such as Karen Ann Quinlan might coincide with the duties apparently imposed by the general homicide statute, which is also an expression of the state's policy of protecting life. The question was whether the equity

6 The current version of the New Jersey statute defining the powers of the court is found at N.J.S.A. $3 B: 12-49$ (1982). The New Jersey code is similarly clear that if a guardian is appointed as to the person or estate of a mentally incompetent person the court still has "a full authority over the ward's person and all matters relating thereto" (N.J.S.A. 3B:12-36 (1982)). 
courts exercising their parens patriae powers ought to feel themselves bound by the homicide statute's implicit directive that treatment might never be withdrawn or withheld from a person defined still as alive, or whether the state in managing the medical affairs of its wards ought to move in the direction of the emerging medical and religious standards for the treatment of permanently unconscious and terminally ill patients.

Let us be clear, therefore, about the particular package of legal questions that were before the New Jersey Supreme Court in the Quinlan case. The interests at stake were those of the patient, her guardian, her family, the doctors, the hospital, the state in its role as enforcer of the general laws of the state, and the state in its role as parens patriae. The precise legal questions before the court were (a) whether to appoint Joseph Quinlan as Karen's guardian and (b) whether to give him explicit authorization to terminate the life-support apparatus. At the time when the case arose, the apparent state of the law was that the state's interest in the preservation of life, expressed in the homicide statute and reinforced by the behavior of the courts exercising their equity probate jurisdiction, was paramount to the interests of families in terminating treatment on patients for whom they assumed responsibilities, and might even outweigh the interests of the patient herself. The Quinlan family, by contrast, relying heavily on the intellectual structure of the Catholic teachings, was arguing (a) that their decision to terminate life-supports on Karen was not morally objectionable and therefore ought not be legally objectionable and (b) that the powers of the family or the patient to make decisions of this nature was protected by the New Jersey and United States Constitutions and could not be interfered with by the state either by a homicide prosecution or by the court's denying the guardianship to Joseph Quinlan or declining to acknowledge, in the declaratory order that they sought, that he had the power to order discontinuance of life-supports.

\section{B. The Guardianship}

Although the core of the legal doctrinal issue was the nature of the state's interest, from which would flow the standards for selecting a guardian, the court chose to address first the question whether Joseph Quinlan was a fit guardian. In context, the consequence of this technique of proceeding was to qualify the guardian first, then to decide that the state's interests might safely be entrusted to him when he was operating through the procedures set forth in the opinion, rather than to decide first on the state's interest and then to authorize the guardian to carry out the state's wishes. The method by which the opinion is constructed is itself symbolic of the deference to family and attending physicians that also is the substance of the legal standard that the court articulates.

This guardianship proceeding was highly unusual. In the ordinary case, there is no occasion to doubt that the guardian of an incompetent patient in a hospital is the patient's next of kin. What is ordinarily required in the hospital setting is a person who can consent on behalf of the patient to medical treatment, and 
consult with the physicians about treatment options. It is not customary to seek the formal appointment of a guardian for an incompetent patient for the purpose of obtaining consent to medical treatment, if the same persons who qualify to be appointed guardian under applicable statutes are in fact participating in the decisions regarding the care of the patient. In addition, it bears pointing out that it is customary for treating physicians and hospital personnel to consult with whatever family members appear to be most informed and involved in the patient's care, not only with the unique individual who would be appointed guardian by the court.

The Quinlans were therefore presumed from the beginning of Karen's hospitalization to be the appropriate persons to make medical decisons for Karen; parents of an unmarried adult incompetent had the statutory preference for the guardianship. ${ }^{7}$ It was only when Joeph Quinlan tried to exercise what he thought was his power to withdraw consent to treatment that the hospital's attorney advised Mr. Quinlan that he did not have that power, forcing the Quinlans into court to request formal letters of guardianship with express authorization to discontinue life-supports. It was in this context that Joseph Quinlan's personal fitness as guardian was drawn into question, the problem being that he had already expressed his belief that his guardianship powers could and ought to be exercised in a manner that informed lawyers would regard as homicide under the New Jersey statute.

The fact that Joseph Quinlan had already made up his mind that no extraordinary measures ought to be taken to preserve Karen's life presented a difficulty for the court. If the court disagreed with the prospective guardian's view of his responsibilities and was disinclined to affirm his power to discontinue the life-support apparatus, it ought not grant him the letters of guardianship at all, because he would be likely to make all of his decisions with respect to treatment in a manner consistent with his own beliefs. At best the court might anticipate continuing tension between the guardian and the treating physicians; at worst, the guardian might use his acknowledged powers in a manner inconsistent with the state's obligations toward the ward. The trial court had resolved this dilemma by appointing Joseph Quinlan the guardian only of the property of Karen; and by appointing another guardian for her person, with authority to make medical decisions for her. The issue of Joseph Quinlan's fitness as guardian was therefore inescapably before the New Jersey Supreme Court because it was being asked to reverse the trial court on this point and grant letters of guardianship to Joseph Quinlan as the guardian of both the person and the property of his daughter.

The fitness of a person for a task depends on the definition of the task. It

7 The New Jersey statute provided that letters of guardianship for a mentally incompetent adult should be granted to the spouse, if the incompetent and spouse were living as man and wife at the time the incompetency arose, or to his heirs. The parents of an unmarried adult are his or her first "heirs" in the line of intestate succession. See the current version at N.J.S.A. 3B:12-25 (1983). 
would be incoherent to address the question of the fitness of Joseph Quinlan as guardian without addressing the question of what he was expected to do as guardian, exercising the powers of the state. It is good practice to think about the usual case before proceeding to consider the kind of extraordinary situation posed by the Quinlan matter. In the ordinary case of intrafamily guardianship, there is little or no judicial supervision of the conduct of the guardian, in the absence of some reason to believe that the guardian is abusing power. The guardian is simply instructed to manage the ward's affairs for the benefit of. the ward. Although the standard by which the guardian is to be guided is the "best interest" of the ward, the courts do not purport to give extensive guidance in particular cases as to what the ward's best interests might be. The guardian exercises his or her judgment as to what is in the ward's interest. To a significant degree, therefore, the guardian designs his or her own task.

In this case, however, it was claimed that there was a limit on the guardian's power to take a specific action. Why? Surely the guardian had general authority to give informed consent to treatment, which necessarily involves the exercise of choice and judgment. It could not be the case, therefore, that the guardian was required to consent to all treatment options preferred by the physicians, since in the exercise of his guardianship powers he had all the powers that the ward might exercise, which includes the power to choose. He clearly had general power to deny as well as to give consent. The question was whether he might refuse to continue consent to this kind of treatment under these circumstances.

This problem comes down to the question whether the guardian has power to exercise all of the medical decision-making power that the ward might herself exercise. The "best interests" test suggests otherwise. That test requires the guardian to administer the property of the ward in a manner that would be thought of as selfish if the ward were to take those same actions. We might think of this as the "selfish best interests" standard. Likewise, the "best interests" standard has been thought to require the guardian to administer the person of the ward in a manner that best promotes the ward's physical, mental and moral well-being, the most basic of these being the physical.

The "best interests" standard has not been, however, the sole measure of the guardian's duty. In the context of managing the financial assets of wards, the courts developed the concept of "substituted judgment" to deal with situations in which a guardian administering a ward's assets under the "best interests" test would be forced to behave more selfishly on the ward's behalf than the ward arguably would have wished. The doctrine of "substituted judgment" was first developed in the eighteenth century in England to allow guardians to contribute, on behalf of their wards, some of their wards' income to the support of family members who required support, on the ground that the ward would have wished to have discharged his or her obligations as a member of a family. The concept traveled to the United States, and has been invoked, for example, to allow guardians to distribute assets to the ward's devisees in advance of the ward's death in order to avoid estate taxes (See Matter of Trott, 118 N.J. Super. 
436,288 A.2d 303 (1972)). Although the concept belongs mainly to the domain of estate planning, and has been used to authorize the guardian to do what a reasonable and prudent person would do in the management of his or her own estate, the concept had been used by several state courts in the medical context to authorize organ transplants between siblings where the donor sibling was mentally incompetent, on the ground that the court may authorize to be done that which the incompetent might do if he had his faculties. The court has, in other words, all of the powers of the incompetent including the power to act against the incompetent's "best interests" narrowly and selfishly defined, if a reasonable and prudent person might so act (See Hart v. Brown, 29 Conn. Sup. 368, 289 A.2d 386 (1972)).

It must be pointed out here that the court has these powers, and that the "substituted judgment" test does not involve a search for the ward's subjective intent or judgment, but rather authorizes the court and guardian to select among the options that a reasonable and prudent person would regard as appropriate exercises of good judgment under the circumstances. Some of those options might not meet the narrow concept of "selfish best interests."

Although the "substituted judgment" concept had been deployed mainly to authorize altruistic acts on behalf of the ward, there was no reason in principle why it might not be deployed to authorize the court and guardian to search for reasonable and prudent treatment options for a permanently unconscious patient where those options might not be regarded as being within the "best interests" of the patient defined narrowly as the preservation of biological life. Indeed, that is exactly how the New Jersey Supreme Court used the concept. The guardianship of Karen Quinlan was to be governed by the "substituted judgment" rather than the "best interests" standard. ${ }^{8}$

Having arrived at this point, the question was how the "substituted judgment" test might be used in the Quinlan context. Joseph Quinlan was arguing that a reasonable and prudent guardian might decide in the circumstances to discontinue use of the respirator that was sustaining Karen's breathing. Once it had been decided that the "substituted judgment" standard applied to define Joseph Quinlan's duty, the question was whether he was correct or not in his assessment of what a reasonable and prudent person might regard as appropriate. This is an empirical inquiry: The question for the court was what the best contemporary thinking was on the problem of terminating treatment.

The court approached that question by inquiring into the quality of Joseph Quinlan's character, motivation and sincerity. Since Quinlan was arguing that his request for power to authorize disconnection of the respirator was in accord with the teachings of his faith, an evaluation of his motivation and sincerity

${ }^{8}$ It bears noting that the logic that has just been traced out is implicit rather than explicit in the opinion: The New Jersey Supreme Court simply invoked the "substituted judgment" test without explaining that it is an exception to the general "best interests" standard, and the court is uncommonly elliptical in its discussion of the implications of having evoked the "substituted judgment" standard in this context. 
afforded the court an opportunity to set forth in some detail in the opinion the Catholic teachings on which Quinlan was relying for guidance. The New Jersey court was not, however, at liberty to authorize Joseph Quinlan to terminate treatment on Karen simply on the ground that that action would have been consistent with the Catholic teaching. ${ }^{9}$ Nor could it adopt the Catholic position as the law of New Jersey simply because it was the Catholic position, or because the teachings went to the heart of the problem of how to think about medical treatment for permanently unconscious patients, and were perhaps at the time the only source of authoritative religious guidance on the problem of refusing to continue life-supports. Under the rules of recognition that apply within civil courts, the teachings of the Catholic Church do not serve as authoritative sources of law. However, the existence or content of religious teachings may be relevant to the formulation or application of a legal standard. In this case, the court treated the Catholic teachings as relevant to three different legal issues: (a) the qualification of Joseph Quinlan to be guardian; (b) the appropriateness of utilizing the "substituted judgment" standard for defining the powers of the guardian in a case involving a permanently unconscious patient; and (c) the range of options that might be regarded as appropriate for the exercise of "substituted judgment."

The interplay between the question of the fitness of the guardian and the content of the "substituted judgment" test as invoked in this setting now becomes apparent. In the evaluation of Joseph Quinlan's qualifications, then, his and his family's Catholic faith, the care that they exercised in coming to the position that they eventually took on the matter of terminating treatment, and the teachings of the Church on the issue of refusing "extraordinary" care become relevant, and the court decides that there is no reason to defeat the statutory order of preference for the appointment of guardian that is in the probate code (Quinlan case 1976, 53).

\section{The State's Interest and the Federal Constitution}

After the court had decided that Joseph Quinlan's petition for guardianship would be granted, it then acted on Quinlan's request that he be authorized to have the respirator disconnected. This bit of ordering in the opinion bears mention. Judicial opinions, although purporting to set out the reasons why the court reached the result that it reached, rarely reflect either the order in which

${ }^{9}$ Joseph Quinlan had argued that the state was required to acknowledge his power to terminate treatment and to refrain from interfering with it because the exercise of his power would constitute the free exercise of his religion, protected under the First Amendment. The court rejected this argument, however, on the ground that a person claiming the right to be free from state inference with conduct based on religious belief must be able to demonstrate that the state would force an action inconsistent with religious belief. In the Quinlan situation, the Catholic teaching was that patients and their families might, not must, refuse extraordinary means of treatment. The case was thus distinguishable from, for example, the case of a Jehovah's Witness who would maintain that being forced to accept a blood transfusion would constitute drinking blood in violation of Biblical command and would result in the damnation of the soul. See 355 A.2d 647, 661-62 (1975). 
the court reached its conclusions or the decision tree that underlies the progression of reasoning. If, as in the Quinlan decision, the court responds to the questions that the petitioner raised in the order in which he raised them, the apparent progression of reasoning in the opinion may well mislead the reader as to the underlying logic of the decision. In addition, a reader who is not conversant with the particular areas of the law that the court invokes may also think that the opinion reveals on its face a larger fraction of the law that one must know in order to understand the opinion than is actually the case. A judicial opinion supplies pieces of a mosaic constantly under construction; the court's reasoning, if competently executed, will have been positioned to be coherent within and consistent with other legal rules and principles that govern the domain. The task of extracting the structure of the reasoning usually requires a knowledge of the domain that goes far beyond the particular opinion being analyzed.

If the Quinlan court had organized its opinion in accordance with the actual structure of its reasoning, the qualifications of the guardian ought to have been evaluated last, not first, since the qualifications could not be determined prior to the court's having defined the task. The choice to proceed by evaluating the guardian first, however, allowed the court the opportunity to set forth early in the opinion the Catholic teachings. These teachings are central to the opinion in both a strategic and a substantive sense. Although the Pope's statement does not and cannot serve as a source of law within the civil courts, it does perform a crucial role in the design of the opinion: The principles that Pius XII articulated - that patients have personal autonomy in consenting or declining to consent to treatment, that families are ordinarily best situated to make critical medical decisions for their mentally incompetent members, that physicians ought to abide by the wishes of patients and their families - are principles deeply embedded in the law, reflected in the doctrine of informed consent and in the statutory preference for next of kin as guardian.

Why, however, did the New Jersey Supreme Court have to rely on the Pope's speech for these principles rather than on prior judicial authorities? Here we encounter a peculiar feature of the practice of judicial opinion-writing, one that has considerable implications for developers of expert systems in law. Courts are strikingly reluctant to invoke fundamental principle in writing opinions if there is an intermediate body of doctrine available to serve as the foundation for their reasoning. Courts tend to assume rather than assert the structure of values that underlies legal doctrine; their caution about using general propositions of law directly in legal reasoning is reflected in the maxim "general principles do not decide specific cases," which reflects a preference for propositions of law that have arisen out of actual decisions in actual cases and that therefore have been part of some exercise in practical reasoning. It is consequently difficult in many areas of the law to find in the body of judicial writing a crisp statement of the principles that inform the areas, even though it may be not at all difficult for skilled lawyers to infer them from the decided 
cases. Although such principles are most often not stated, they are nevertheless lurking there as a kind of shadow logic. ${ }^{10}$ When, then, a court needs to invoke fundamental principle, and to cite authority for that principle, it may have difficulty finding judicial authority; yet, if the court articulates the principle in its own voice the court may appear to be inventing the principle rather than articulating what is understood among practitioners to be part of the essential intellectual structure of the field. Pius XII's speech to the anesthesiologists, of course, articulates principles that are common both to the common law and to Catholic doctrine; but the court's having accorded such prominence to it must be regarded as a reflection of the court's inability to find judicial authority directly on point, which the Pope's statement most robustly was.

Pope Pius' statement also has the great merit, from the point of view of the court, of setting up the conflict as one occurring between patients and their families, on the one hand, and physicians on the other. This is a plausible characterization of the practical problem that families such as the Quinlans were facing, because it was the physicians' and hospital's insistence on continuing to provide the life-supports that gave rise to the legal conflict with the family. In the contemplation of the law, however, the physicians had no legal privilege to continue treatment once begun simply because they would have preferred to continue it. If someone has the power to withdraw consent and they exercise that power, then the physician cannot continue to treat without committing battery. The only reason why the physicians could assert a privilege to continue to treat over the patient's family's objection was that the state, in its parens patriae function through the probate court, was unwilling to delegate to the guardian authority to withdraw consent to treatment. The legal question before the New Jersey Supreme Court was whether it should allow its probate courts the power to withdraw consent, and, if so, whether the power might be delegated to a guardian. The central issue in the case, therefore, was the state's interest, since the state might override the wishes of patient or family; and the question was whether the state was going to side with the physicians or the family or chart an independent course.

The Quinlan situation posed an interesting dilemma for the court. Once having invoked the "substituted judgment" standard to govern medical decision-making for permanently unconscious patients, it had to decide what powers to allow the probate courts in using that standard. The danger was that the "substituted judgment" standard would allow probate courts and guardians to act against medical advice, raising the possibility that medical professionals might be required to take actions that they felt did not comport with their professional standards and responsibilities, which the state itself recognizes and enforces in the malpractice standard. The question was whether the "substituted judgment"

10 Drawing out the shadow logic of judicial reasoning is one of the principal functions of the kind of academic writing that consists of making true statements about the law. Susskind refers to this kind of statement as a "law-statement" (Susskind 1987, 34-40). 
standard might be used to force medical professionals to commit an act that professionals would regard as not in accord with their best judgment in light of standards and practices prevailing in the profession. The court's answer to this question is unequivocally in the negative, although its reasoning is unclear. It observes that although the courts have the power to exercise "substituted judgment" it is inappropriate for them to overrule medical decisions made in accordance with "standards and practice prevailing in the profession" (Quinlan case 1976,45$)$. Therefore, the court holds, the lower court was correct in not authorizing withdrawal of the respirator, because Karen's physicians had made their decision in accordance with existing medical standards and practices as they understood them and as they had been proved in the trial in the lower court (Quinlan case 1976, 45).

In context, this holding seems anomalous. The Quinlans had, after all, asked for authority to have the respirator on Karen disconnected, which would seem to mean authority to tell the particular physicians to disconnect the respirator. It was odd, therefore, for the New Jersey Supreme Court to begin its discussion of the state's interest by approving the decision of the trial court not to order the discontinuance of the respirator. Moreover, the court appears to hold that the probate court has a duty to medical professionals not to order them to practice medicine in a manner inconsistent with their standards even when exercising the parens patriae power under the "substituted judgment" standard. In fact, however, this part of the opinion displays the subtlety of the court's approach to the matter. The court separates the question (a) whether the court acting on behalf of the patient has authority to withdraw consent to treatment from the question (b) whether the court can order particular unwilling medical professionals to deliver the specific kind of treatment that the court wants the ward to receive. The court responds by affirming the trial court's decision in declining to authorize withdrawal of the respirator, although clearly recognizing the authority of the court to authorize such withdrawal, and thus protects the conscience of the individual medical professional.

The conscience of the individual medical professional is not to be confused, however, with the standards of the medical profession itself. These, insofar as the court understands them, are central to the court's analysis of the state's interest. Let us recall the court's dilemma. It is that the policy of the homicide statute may be an inappropriate guide to the exercise of the state's parens patriae responsibility toward permanently unconscious or terminally ill patients. If the homicide statute is not to control, and if the "substituted judgment" standard is to be used, to what should a court or guardian exercising "substituted judgment" look for guidance as to what the state's interest is? The standard is that "substituted judgment" may be used to select an option that a reasonable and prudent person would select. In this case, the question would be whether a reasonable and prudent person would select termination of the life-support apparatus.

Of course there is no compelling reason why a reasonable prudent person 
should be confined to a range of treatment options that allopathic physicians view as appropriate, and the court does not assert that the "substituted judgment" standard is bounded by conventional medical practice. The question that the court asks is this: Is there a universal medical standard for treatment for permanently unconscious and terminally ill patients so contrary to the granting of the authority that Joseph Quinlan is requesting that the state should bar the relief that he seeks? (Quinlan case 1976, 45). This question implies some close relationship between the state's interest and the medical standards of care, but it is not clear what that interest is because the court in this case looks to the medical standards of care only to determine whether they bar the treatment option that the guardian prefers. Most tellingly, in this situation the court finds that it is actually in the state's interest as parens patriae to take account of the fact that physicians must terminate treatment on some patients, because it is likely that the treatment decisions that the physicians actually make are influenced by their fear of liability, inducing a self-regarding consideration into medical decision-making that detracts from the physician's inclination to consider foremost the interests of the patient (Quinlan case 1976, 46).

Does, then, the state have a parens patriae interest in this case that leads it to compel the continuance of life-supports for Karen? The opinion discards every ground in state law for thinking so. Moreover, the court deploys the emerging federal constitutional jurisprudence of privacy to throw a cloak of federal constitutional protection over the power of Karen and her father, acting, as guardian, to discontinue treatment. This point is worth mentioning, because the court's invocation of the federal privacy interest can easily mislead a less than careful reader into believing that In re Quinlan is primarily "based on" Roe $v$. Wade (410 U.S. 113, 93 S.Ct. 705, 35 L.Ed. 2 d 147 (1973)) the case in which the United States Supreme Court invalidated state regulation of early abortions, basing the decision on federal constitutional privacy interests. It is true that the New Jersey Supreme Court cites Roe v. Wade for the proposition that a federal privacy interest that is broad enough to encompass a woman's right to terminate a fetus is broad enough to encompass a patient's decision to decline medical treatment under certain circumstances (Quinlan case 1976, 40). However, a close reading of the Quinlan decision reveals that it actually turns on an analysis of the state's interest; the federal constitutional point adds weight to the court's analysis of state law, and it effectively immunizes the result from any action on the part of the New Jersey legislature.

The New Jersey court approaches the federal constitutional question in the manner characteristic of federal constitutional analysis, weighing the patient's interest in privacy against the state's interest in preserving her life. The New Jersey Supreme Court does not relinquish any of the state's traditional interests in protecting life, preventing suicide, protecting the rights of third parties, or protecting the ethics of the medical profession, which have been held to justify the state's exercise of its power to override a patient's nonconsent to treatment. However, the Court finds that a permanently unconscious chronically vegetative 
patient has a federally protected privacy interest in refusing medical treatment that only prolongs that condition with no hope of recovery, and that the patient's interest outweighs, in the circumstances of the Quinlan situation, the state's interests in the preservation of the patient's own life (Quinlan case 1976, 41).

The Court arrives at this proposition by examining the rights of the competent adult patient, who is the paradigmatic legal actor in the American legal system. A competent patient ${ }^{11}$ in Karen's condition, the Court points out, could never be subjected against her will to the type of treatment that Karen was receiving, the state's interest in the preservation of the patient's life does not extend to the imposition of painful, intrusive treatments when the prognosis is dim.

What happens when the patient becomes incompetent? The court holds that Karen does not lose her right of privacy simply by virtue of having become incompetent. However, the definition of that right becomes problematic. On the one hand, the court says repeatedly that the family and guardian may "assert" Karen's rights on her behalf. On the other hand, not all of the powers that Karen would have had while competent transfer to her guardian. When the patient becomes incompetent, the powers that she had as a competent person lapse. She becomes a ward of the state, which has considerable powers and duties with respect to her. It is the state's powers and duties that are delegated to the guardian; the guardian does not acquire powers or rights as the incompetent's surrogate. The question for the court is: What powers should the guardian of a patient in Karen's circumstances have in light of the constitutionally protected privacy interests that she retains.

The New Jersey court does not attempt to decide Karen's present privacy right; rather, it decides that the only "practical way" to protect that right is to allow her guardian and family to decide how she would have exercised it in her present circumstances. Operationally, this means that the actual content of Karen's federally protected privacy right consists of an authorization to her guardian to exercise "substituted judgment" within the procedural constraints laid down by the court. The court thus arrives at the same practical result on analyzing both state and federal claims.

The content of the federally protected right, as the New Jersey court articulates it, turns out to be just what the court thinks appropriate under New Jersey law in

11 In 1975, it was not clear what privilege to refuse treatment a competent patient might have had, what right to be free of government interference with the exercise of that privilege; and in any event a competent patient could not have been in Karen's precise situation because the distinguishing feature of her situation was her loss of cognitive capacity. The court tries to imagine a competent Karen. "We have no doubt. . . that if Karen were herself miraculously lucid for an interval (not altering the existing prognosis of the condition to which she would soon return) and perceptive of her irreversible condition, she could effectively decide upon discontinuance of the life-support apparatus, even if it meant the prospect of natural death" (Quinlan case 1976, 39). At best, one might talk of the autonomy and preferences that the patient had prior to becoming unconscious. However, evidence of Karen's previously stated preferences and intentions had been regarded by the trial court as not probative of Karen's considered wishes because they were "remote and impersonal" (Quinlan case 1976, 22). There was thus little reliable evidence of how the patient would have exercised her autonomy had she been able to do so. 
light of its considered understanding of New Jersey's parens patriae interest. That is, the New Jersey court appears to hold that Karen has a right that the guardian be equipped with authority to exercise a fiduciary judgment as to what a reasonable and prudent person in Karen's situation might want to have done. The standard is objective, not subjective, as in the circumstances of the Quinlan case it must be since Karen's actual wishes could not be ascertained. The patient is still to be protected by having a guardian governed by a fiduciary standard and acting within the procedures set forth by the court.

\section{Rights and Institutions}

Now we come to the rights and duties of the physicians and the hospital in light of the power and duties of patient, guardian and court as outlined above. One conspicuous feature of the Quinlan decision is that it is a practical decision about patient care decision-making within an acute care general hospital, and the order in the case reflects the court's understanding about how the hospital as an institution works. The order is for this reason very specific in setting forth the procedures that must be followed if the exception to the homicide statute is to be invoked. Although the language of the opinion sounds mainly in individual rights discourse, when it comes to fashioning a remedy, the New Jersey Supreme Court takes a view of its problem that resonates more with concepts of administrative law than of constitutional law. The order itself is explicit that it is the physician, not the family, who initiates the sequence of actions that can result in discontinuance of the lifesupport apparatus. The physician makes the prognosis that the patient will not return to a cognitive, sapient life and the decision that the life-support ought to be discontinued. The guardian and family are involved in the process by having the power to concur, or decline to concur, in this decision; and the role of the ethics committee is to concur, or decline to concur, in the prognosis.

For someone who might have read the "constitutional rights" talk in the opinion as expressing the court's understanding that the opinion rests upon the personal autonomy of patient and family, the actual order may come as a surprise. The order is, however, fully consistent with the court's view of the proper allocation of authority under the "substituted judgment" test within the hospital. What the court is at pains to do in the Quinlan order, therefore, is to surround the guardian's decision with institutional constraints of the sort available in a modern hospital. The guardian merely concurs in a medical judgment that must be made by the attending physician; only after the attending physician has decided that the patient is unlikely to return to a cognitive, sapient state and the guardian and family have concurred, is the ethics committee to be consulted. And the physician, with the concurrence of the guardian and family, makes the decision that the life support apparatus should be disconnected. The guardian's real authority is in the choice to concur or not in the physician's decision and in the selection of the physician and hospital; but a change in either physician or hospital might be difficult as a practical matter.

What is notable about the actual order for declaratory relief in the Quinlan 
case, therefore, is that it reflects the New Jersey Supreme Court's concern for the multiplicity of legal interests and legitimate concerns of the many persons involved in the case and the integrity of the decision-making process with respect to discontinuing treatment of chronically vegetative patients rather than reflecting, as one might expect from the opinion, a more narrowly focused analysis of the rights of the parties. And so the final lesson of the Quinlan case for the expert systems developer is that courts not only think about rules and concepts; they create them. Courts also think about institutions, and the control of institutional decision-making through legal standards - and they create both of them, too! None of the lawyers in the Quinlan case anticipated that the order as it came down would be so focused on procedural protections, which may be to say that even good lawyers cannot think of everything.

\section{Expert System of In re Quinlan}

In In re Quinlan, the New Jersey Supreme Court issued the order for declaratory relief that follows. (Quinlan case 1976, 54. Spacing is introduced to make the parts and the relationships between them more apparent.)

...we herewith declare the following affirmative relief on behalf of the plaintiff.

Upon the concurrence of the guardian and family of Karen,

should the responsible attending physicians conclude

that there is no reasonable possibility of Karen's ever emerging from her present comatose condition to a cognitive, sapient state and

that the life-support apparatus now being administered to Karen should be discontinued,

they shall consult with the hospital "Ethics Committee" or like body of the institution in which Karen is then hospitalized.

If

that consultative body agrees that there is no reasonable possibility of Karen's ever emerging from her present comatose condition to a cognitive, sapient state,

the present life-support system may be withdrawn and

said action shall be without any civil or criminal liability therefor on the part of any participant, whether guardian, physician, hospital or others. (Footnote 10) We herewith specifically so hold.

Footnote 10. The declaratory relief we here award is not intended to imply that the principles enunciated in this case might not be applicable in divers other types of terminal medical situations such as those described by Drs. Korein and Diamond, Supra, not necessarily involving the hopeless loss of cognitive or sapient life.

Our legal expert's structural interpretation of this declaratory order and its qualifying footnote, has been transformed into Clear Normalized Form. This 
version of the interpretation, which is set forth in Appendix B, is automatically generated when an appropriate input file is used with the NORMALIZER software. NORMALIZER also generates the Quinlan Clear Mnemonic Arrow Diagram and the Clear Mnemonic Outline. The Prolog code for the QUINLAN LES is generated by AUTOPRO from the same input file. The Clear Mnemonic Arrow Diagram, the Clear Mnemonic Outline, and the input file for the two computer programs are also included in Appendix B.

In the hypothetical situation described in Section 2, when the prosecutor consults the QUINLAN LES or its corresponding normalized version, she will find drastically different results with respect to the criminal and civil liability of the physicians for disconnecting the respirator. The record of her consultation with QUINLAN LES is also included in Appendix B.

\section{Synthesis of Related Expert Systems}

The contradictory results inferred by the NJ2C-11 LES and the QUINLAN LES in the exact same hypothetical situation points up the need for some corrective action with respect to one or both of these systems. Is one of the systems "wrong" or "incomplete" in some sense? Are the sets of legal rules that now define these two expert systems somehow related in the New Jersey legal system in a way that is not now embodied in the two separate expert systems? Asking these questions about the NJ2C-11 LES helps clarify the limitations of this expert system in its present form and its scope of coverage. The NJ2C-11 LES described in Section 2 deals only with selected parts of the express provisions of Title 2C, Chapter 11 of the New Jersey statutes. It does not even include other conditions that are explicitly expressed elsewhere in the New Jersey statutes ${ }^{12}$ let alone other qualifications expressed or implied in other parts of the New Jersey or federal legal systems. The ruling in In re Quinlan is one such qualification - both (1) a delineation of the powers of guardians of permanently unconscious patients under the New Jersey Probate Code, and (2) an interpretation of the unwritten constitutional right of privacy found by the United States Supreme Court in Griswold v. Connecticut (381 U.S. 479, 484, 83 S.Ct. 1678, 1681, 14 L.Ed.2d 510, 514 (1965)) to exist in the penumbra of specific guarantees of the Bill of Rights "formed by emanations from those guarantees that help give them life and substance." Chief Justice Hughes in the Quinlan case declared for a unanimous New Jersey Supreme Court:

12 E.g., (a) the general principles of liability in Title 2C, Chapter 2 (including, but not limited to, requirements for a voluntary act, culpability, and a sufficient causal relationship between conduct and result, and also including defenses for ignorance or mistake, intoxication, duress, consent, or entrapment); (b) the general principles of justification in Title 2C, Chapter 3 (including, but not limited to necessity, execution of public duty, and the use of force in self protection, for the protection of other persons, in defense of premises or personal property, in law enforcement, or by persons with special responsibility for care, discipline or safety of others); and (c) the requirements for responsibility in Title $2 \mathrm{C}$, Chapter 4. 
Presumably this right [of privacy] is broad enough to encompass a patient's decision to decline medical treatment: under certain circumstances, in much the same way as it is broad enough to encompass a woman's decision to terminate pregnancy under certain conditions. (Roe v. Wade, 410 U.S. 113, 153, 93 S.Ct. 705, 727, 35 L.Ed.2d 147, 177 (1973))

One approach for resolving incompatibility between two or more legal expert systems such as that described above for the NJ2C-11 LES and the QUINLAN LES is to integrate them into a combined system that eliminates the incompatibility. Building such a combined system requires the same sort of legal expertise needed for writing a legal treatise on the subject. It requires that additional rules be formulated that relate the rules of the separate systems. In the case of these two expert systems such additional rules must be editorially extracted from what is stated in the Quinlan opinion and related to the rules expressed in the NJ2C LES and the QUINLAN LES in a way that eliminates the incompatibility.

Another approach would be to synthesize multiple systems that are related by furnishing guides that help assure use of the multiple systems in a coordinated way that will enable a careful user to avoid the incompatibility. When a user is consulting a LES that is related to another LES, at the occurrence of the exact word or phrase that is the juncture where the two legal expert systems are related, the user can be alerted to the existence of the related LES and given an opportunity to consult it before responding to the question being posed by the first LES. Other forms of assistance can also be made available at this same point to assist in avoiding what seems to be an incompatibility. This second approach is the one explored here and illustrated in Appendix C.

In the Quinlan case the New Jersey Supreme Court was dealing with the possible application of N.J.S.A. 2A:113-1, a statute defining murder that has since been replaced by Chapter 11 . That statute explicitly required that the killing be an unlawful one (see N.J.S.A. 2A:113-1). In the Quinlan case the New Jersey Supreme Court declared:

...We conclude that there would be no criminal homicide in the circumstances of this case. We believe, first, that the ensuing death would not be homicide but the expiration from existing natural causes. Secondly, even if it were to be regarded as homicide, it would not be unlawful.

These conclusions rest upon definitional and constitutional bases. The termination of treatment pursuant to the right of privacy is, within the limitations of this case, ipso facto lawful. Thus, a death resulting from such an act would not come within the scope of homicide statutes proscribing only the unlawful killing of another. There is a real and in this case determinative distinction between the unlawful taking of the life of another and the ending of artificial life-support systems as a matter of self-determination. (Quinlan case 1976,51 )

By its enactment of the Code of Criminal Justice in 1979 the New Jersey legislature removed the requirement of unlawfulness from the definition of criminal homicide. Thus, the basis for the second part of the court's holding - namely, that even if the actions in the Quinlan case were homicide, they did not 
amount to criminal homicide because they were not unlawful - has been rendered moot by legislative repeal of the statute. This legislative change has not, however, affected the first part of the court's holding - that the subsequent death would not be homicide but expiration from existing natural causes - as the basis for linkage to the criminal homicide provisions of Chapter 11. Hence, the Quinlan case should be operationally linked to the person_causes condition expressed in subsection $1 \mathrm{~A}$ of the normalized representation of the $\mathrm{NJ} 2 \mathrm{C}-11$ LES as an elaboration or explanation of the meaning of "a person purposely, knowingly, recklessly, or, by driving a vehicle recklessly, CAUSES the death of another human being" in the coordinated legal expert systems. (See the normalized version of Chapter 11 in Appendix A.)

From a user's point of view the coordinated legal expert systems would operate in the following manner. When the question about causing death is presented, along with the user's alternative choices, the user would be alerted to select the "Definition" alternative by the highlighted word "CAUSES" in the question. (The " " in the highlighted term "CAUSES" indicates that there is at least one legal expert system available that deals with how this term is to be interpreted for purposes of answering the question.)

person_causes

In the situation that you are analyzing is it the case that a person purposely, knowingly, recklessly, or, by driving a vehicle recklessly, CAUSES* the death of another human being?

Choose
Yes
No
Unknown
Help
Definition
Pause
Stop

Upon selecting the "Definition" alternative and getting the definition for CAUSES the user is provided with text that discusses various situations in which conduct does result in death of another human being and various situations in which conduct does not result in such death. Included among the situations where conduct is deemed not to cause death is a description of the Quinlan case as one involving comatose patients and discontinuance of treatment by physicians. Here, users are advised that if they think that their situation is sufficiently like Quinlan, they should respond to the person_causes question with "No," and users that think that their situation might be like Quinlan are advised to select "Pause" and either to consult normalized versions of our expert's interpretation of the Quinlan order for declaratory relief or to consult the QUINLAN LES. When users consult either, they will access the interpretation of the expert whose expertise is embodied there. 
With the coordination of the use of the two legal expert systems in this manner, a user has the option of answering the person_causes question "Yes" or "No" without ever consulting the QUINLAN LES or the normalized versions of the Quinlan rules, or alternatively, the user can make choices that will delay the selection of one of those answers until after an examination of the normalized rules or consultation with the QUINLAN LES occurs.

The exercise of coordinating and structuring the use of related legal expert systems as a way of synthesizing related legal rules from statutory and case (and even constitutional) sources has some important lessons for all who are interested in the potentialities and limitations of such systems. The coordination of the NJ2C-11 LES and the QUINLAN LES illustrates one way that legislative statutes and court case decisions can be synthesized, and it is a useful step forward in that respect.

On the other hand, this example is a sober reminder of the magnitude of the task of constructing legal expert systems that will be practically useful to legal practitioners and researchers. Imagine the enormity of what confronts a LES builder seeking to build an expert system on murder in New Jersey before the Quinlan case occurred. Would such a builder have the incentive, inclination, resources, or knowledge to be led to speculating about whether unwritten federal constitutional rights of personal privacy of individuals to noninterference from the state in the purchase and use of contraceptives and to the termination of pregnancy is likely to be interpreted to encompass noninterference from the state in a patient's choice to decline treatment? Such a LES builder would have to be concerned about all the many possible exceptions to the general rules about murder. The task would not be the focused one faced by the attorney for the Quinlan family, nor would the motivation or resources to research and construct a persuasive argument for an exception springing from an interpretation of privacy rights be the same. What makes building a LES that embodies rules about future court decisions overwhelming, is the unavailability of a clear crystal ball that will unerringly predict future human behavior - in particular, the decisions that judges will make in disputes that come before them and statutes that legislatures will enact on matters of social policy.

Even when a builder is confident about what a court is likely to decide in the future, there is still open the question of how widely its effects are likely to be. For example, if the United States Supreme Court were to undercut the position it took in Roe $v$. Wade on a woman's privacy right to noninterference from the state in having an abortion, to what extent, if at all, would that affect the privacy rights of patients to noninterference by the state in their exercise of choices to not receive treatment from physicians?

It is a much different and far easier matter to build expert systems based on court decisions that have already been made, rather than upon what courts are likely to do in future disputes. For now, attention of LES buildings on rules articulated in past decisions is likely to be more fruitful than speculations about possible rules for probable future decisions, even though users' concerns are 
chiefly with what is likely to happen in the future. Those concerns are perhaps best addressed by achieving a deep, precise, and complete understanding of what has been happening with respect to such decisions in the recent past.

\section{Conclusion}

In their work lawyers need to be informed about legal rules from constitutions, statutes, court opinions, regulations, administrative rulings, and other sources. By extensive indexing and other reference aids, manual methods with books provide legal researchers with cues for finding rules that are possibly relevant to their current problems. Virtually always, not all of the rules and other useful information is to be found in a single volume. However, the contents of different volumes in the legal literature are related by an elaborate connective structure that enables a lawyer to move deftly among large numbers of different sources to extract the most relevant information. It seems likely that legal expert systems will similarly need to take into account legal rules from a wide variety of sources and will be unable to embody all of them in a single LES. Connective structure between one LES and others will need to be developed that will help guide a user from where she starts to each other LES that is available and relevant for dealing with the problem at hand. The inadequacy of separate isolated expert systems is apparent in the example of the ones described here for the Quinlan case and the New Jersey criminal homicide statute. One means of dealing with their incompatibility as isolated systems is to provide connective structure that relates them in a way that the systems can be used in a coordinated manner that reduces the likelihood of getting results that seem to be incompatible. One example of such structure has been illustrated here; we expect that many others will be invented, considerably more clever than this initial effort, as developers of legal expert systems become aware of the problem of providing connective structure and turn their attentions to dealing with it. Nothing has been said here about the 180 alternative structural interpretations of the order for declarative relief issued in the Quinlan case, each of them different and each of them leading to a different LES. These 180 different legal expert systems also need to be related to each other and other legal expert systems in a way that will get to the attention of legal researchers dealing with problems that involve them, ... but that, and similar alternative interpretations of the New Jersey criminal homicide statute, is a story for another paper. 


\section{Appendix A. NJ 2C-11 Legal Expert System}

\section{Parts of Chapter 11 of the New Jersey Code of Criminal Justice}

\section{C:11-1 Definitions}

In Chapter 11 through 15, unless a different meaning plainly is required:

a. "Bodily injury" means physical pain, illness or any impairment of physical conditions;

b. "Serious bodily injury" means bodily injury which creates a substantial risk of death or which causes serious, permanent disfigurement, or protracted loss or impairment of the function of any bodily member or organ;

c. "Deadly weapon" means any firearm or other weapon, device, instrument, material or substance, whether animate or inanimate, which in the manner it is used or is intended to be used, is known to be capable of producing death or serious bodily injury or which in the manner it is fashioned would lead the victim reasonably to believe it to be capable of producing death or serious bodily injury.

\section{2-C:11-2. Criminal homicide}

a. A person is guilty of criminal homicide if he purposely, knowingly, recklessly, or, under the circumstances set forth in section $2 \mathrm{C}: 11-5$, causes the death of another human being.

b. Criminal homicide is murder, manslaughter or death by auto... [The rest of $11-2 b$ and 11-2.1 have been omitted here.]

2C:11-3. Murder

a. Except as provided in section 2C:11-4 criminal homicide constitutes murder when:

(1) The actor purposely causes death or serious bodily injury resulting in death; or

(2) The actor knowingly causes death or serious bodily injury resulting in death; or

(3) It is committed when the actor, acting either alone or with one or more other persons, is engaged in the commission of, or an attempt to commit, or flight after committing or attempting to commit robbery, sexual assault, arson, burglary, kidnapping or criminal escape, and in the course of such crime or of immediate flight therefrom, any person causes the death of a person other than one of the participants; except that in any prosecution under this subsection, in which the defendant was not the only participant in the underlying crime, it is an affirmative defense that the defendant:

(a) Did not commit the homicidal act or in any way solicit, request, command importune, cause or aid the commission thereof; and

(b) Was not armed with a deadly weapon, or any instrument, article or substance readily capable of causing death or serious physical injury and of a sort not ordinarily carried in public places by law-abiding persons; and

(c) Had no reasonable ground to believe that any other participant was armed with such a weapon, instrument, article or substance; and

(d) Had no reasonable ground to believe that any other participant intended to engage in conduct likely to result in death or serious physical injury.

b. Murder is a crime of the first degree...

(The rest of subsection b., as well as subsections c., d., e., f., and g., are long and complex subsections that deal with sentencing and other matters that are peripheral to our concerns here; they are, therefore, omitted.)

2C:11-4. Manslaughter

a. Criminal homicide constitutes aggravated manslaughter when the actor recklessly causes death under circumstances manifesting extreme indifference to human life.

b. Criminal homicide constitutes manslaughter when: 
(1) It is committed recklessly; or

(2) A homicide which would otherwise be murder under section 2C:11-3 is committed in the heat of passion resulting from a reasonable provocation.

c. Aggravated manslaughter is a crime of the first degree. Manslaughter is a crime of the second degree.

2C:11-5. Death by auto

a. Criminal homicide constitutes death by auto when it is caused by driving a vehicle recklessly.

b. Death by auto is a crime of the fourth degree.

c. For good cause shown the court may, in accepting a plea of guilty under this section, order that such plea not be evidential in any civil proceeding.

\section{C:11-6. Aiding suicide}

A person who purposely aids another to commit suicide is guilty of a crime of the second degree if his conduct causes such suicide or an attempted suicide, and otherwise of a crime of the fourth degree.

\section{Clear Mnemonic Arrow Diagram of NJ 2C-11, Criminal Homicide}

(see diagram on facing page)

\section{Clear Normalized Form of NI 2C-11, Criminal Homicide}

1. IF

* A. a person purposely, knowingly, recklessly, or, by driving a vehicle recklessly, THEN causes the death of another human being,

B. the person is guilty of criminal homicide, AND

C. IF

- 1) the actor purposely causes death or serious bodily injury resulting in death, $O R$

2) the actor knowingly causes death or seriuos bodily injury resulting in death, OR

3) A. the criminal homicide is committed when the actor, acting either alone or with one or more other persons, is engaged in the commission of, or an attempt to commit, or flight after committing or attempting to commit robbery, sexual assault, arson, burglary, kidnapping or criminal escape, AND

B. in the course of such crime or of immediate flight therefrom, any person causes the death of a person other than one of the participants, AND

C. 1) the defendant was the only participant in the underlying crime, OR

2) the defendant did commit the homicidal act or in some way solicit, request, command, importune, cause or aid the commission thereof, OR

3) the defendant was armed with a deadly weapon, or some instrument, article or substance readily capable of causing death or serious physical injury and of a sort not ordinarily carried in public places by law-abiding persons, OR

4) the defendant had reasonable ground to believe that some other participant was armed with such a weapon, instrument, article or substance, OR

5) the defendant had reasonable ground to believe that some other participant intended to engage in conduct likely to result in death or serious physical injury, 


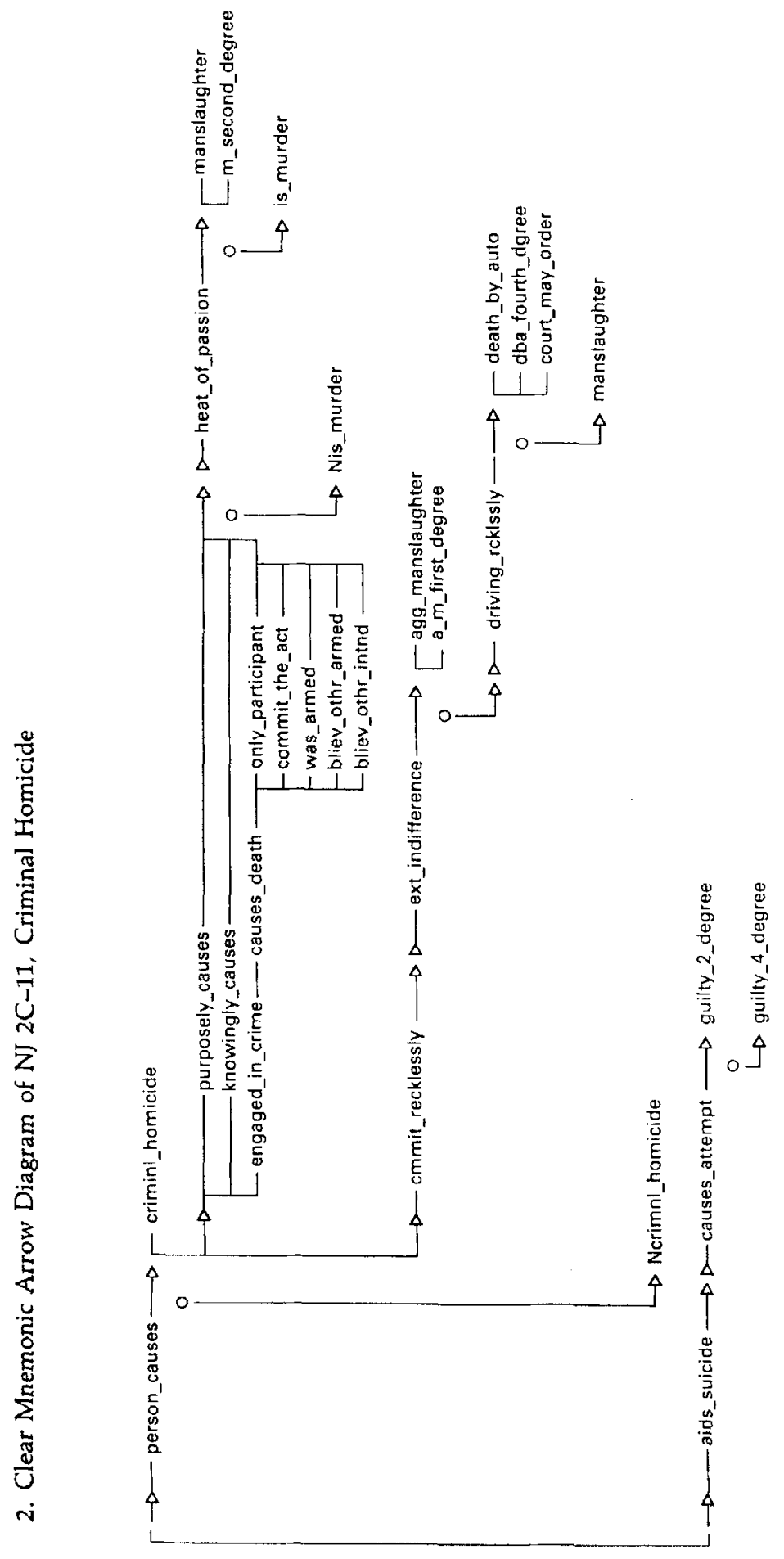




\section{THEN}

4) IF

A. the homicide is committed in the heat of passion resulting from a reasonable provocation,

THEN

B. the criminal homicide constitutes manslaughter, AND

C. manslaughter is a crime of the second degree,

BUT OTHERWISE,

D. the criminal homicide constitutes murder,

BUT OTHERWISE,

5) IT IS NOT SO THAT

the criminal homicide constitutes murder, AND

D. IF

1. the criminal homicide is committed recklessly,

THEN

2. IF

A. the actor recklessly causes death under circumstances manifesting extreme indifference to human life,

THEN

B. the criminal homicide constitutes aggravated manslaughter, AND

C. aggravated manslaughter is a crime of the first degree,

BUT OTHERWISE,

D. IF

1. the criminal homicide is caused by driving a vehicle recklessly,

THEN

2. the criminal homicide constitutes death by auto, AND

3. death by auto is a crime of the fourth degree, AND

4. for good cause shown the court may, in accepting a plea of guilty under this subsection, order that such plea not be evidential in any civil proceeding,

BUT OTHERWISE,

5. the criminal homicide constitutes manslaughter,

BUT OTHERWISE,

\section{E. IT IS NOT SO THAT}

2. IF

the person is guilty of criminal homicide, AND

A. a person purposely aids another to commit suicide,

THEN

B. IF

1. that person's conduct causes such suicide or an attempted suicide,

THEN

2. that person is guilty of a crime of the second degree,

BUT OTHERWISE,

3. that person is guilty of a crime of the fourth degree.

The * indicates a statement that has been interpreted and for which at least one legal expert system has been built that embodies that interpretation (or a statement that contain words or phrases that have been interpreted and for which such a LES has been built).

You can access the LES that is about the interpretation by:

1. running the Primary LES to which the Interpretive LES is related, and

2. selecting the "Help" option when the first question is presented, and

3. pressing the $\langle F 10\rangle$ key, and

4. selecting the Interpreted Term from the index, and 
5. choosing which situation seems most like the situation that you are analyzing to access the most appropriate LES.

$\begin{array}{ll}\text { INTERPRETED TERM } & \text { PRIMARY LEGAL EXPERT SYSTEM } \\ \text { def_causes } & \text { NJ2C-1I }\end{array}$

4. Input File to Generate Arrow Diagrams and

Normalized Versions with NORMALIZER and to

Generate the Legal Expert System with AUTOPRO

NEW JERSEY CODE OF CRIMINAL JUSTICE

2C:11-3. Murder

Interpretation of Professor Layman E. Allen

$>\quad$ (person_causes

\& ((purposely_causes | knowingly_causes

(engaged_in_crime \& causes_death \&

(only__participant | commit_the_act | was_armed |

believ_othr__armed | bliev__othr__intnd)))

$>$ (heat_of_passion $>$ manslaughter $\& \mathrm{~m}$ __second_degree $\mathrm{BO}$ is__murder)

$\mathrm{BO} \sim$ is murder)

\& (cmmit recklessly

$>$ (ext_indifference

$>$ agg manslaughter \& a_. m. first_degree

BO (driving_roklssly

$>$ death_by_auto \& dba_fourth_dgree \& court_may_order

BO manslaughter)))

$\mathrm{BO}$ - crimnl_homicide)

$\&$
(aids_suicide
$>\quad$ (causes_attempt
$>$ guilty_2_degree
BO guilty_4_degree))

Chapter 11 of the New Jersey Code of Criminal Justice

2C:11-2. Criminal homicide

MNEMONIC DETAILED MARKED VERSION

[crimnl homicide: the person is guilty of criminal homicide]

[person_causes: a person purposely, knowingly, recklessly, or, by driving a vehicle recklessly, causes the death of another human being]

2C:11-3. Murder

MNEMONIC DETAILED MARKED VERSION

[is_murder: <the> criminal homicide constitutes murder]

[purposely_causes: the actor purposely causes death or serious bodily injury resulting in death]

[knowingly__causes: the actor knowingly causes death or serious bodily injury resulting in death]

[engaged in_crime: the criminal homicide is committed when the actor, acting either alone or with one or more other persons, is engaged in the commission of, or an attempt to commit, or flight after committing or attempting to commit robbery, sexual assault, arson, burglary, kidnapping or criminal escape] 
[causes_death: in the course of such crime or of immediate flight therefrom, any person causes the death of a person other than one of the participants]

[only_participant: the defendant was the only participant in the underlying crime]

[commit_the_act: the defendant did commit the homicidal act or in some way solicit, request, command, importune, cause or aid the commission thereof]

[was armed: the defandant was armed with a deadly weapon, or some instrument, article or substance readily capable of causing death or serious physical injury and of a sort not ordinarily carried in public places by law-abiding persons]

[bliev_othr_armed: the defendant had reasonable ground to believe that some other participant was armed with such a weapon, instrument, article or substance]

[bliev_othr__intnd: the defendant had reasonable ground to believe that some other participant intended to engage in conduct likely to result in death or serious physical injury]

[heat_of_passion: $\{a\}<$ the $>$ homicide (which would otherwise be murder under section $2 C: 11-3$ ] is committed in the heat of passion resulting from a reasonable provocation].

2C:11-4. Manslaughter

MNEMONIC DETAILED MARKED VERSION

[agg_manslaughter: the criminal homicide constitutes aggravated manslaughter]

[ext indifference: the actor recklessly causes death under circumstances manifesting extreme indifference to human life]

[manslaughter: the criminal homicide constitutes manslaughter]

[cmmit_recklessly: $\{\mathrm{It}\}<$ the criminal homicide is committed recklessly]; or

[heat__of_passion: the homicide is committed in the heat of passion resulting from a reasonable provocation].

[a_m_first_degree: aggravated manslaughter is a crime of the first degree]

[ $\mathrm{m} \_$second_degree: manslaughter is a crime of the second degree].

2C:11-5. Death by auto

MNEMONIC DETAILED MARKED VERSION

[death_by_auto: the criminal homicide constitutes death by auto]

[driving_rcklssly: the criminal homicide is caused by driving a vehicle recklessly]

[dba fourth_dgree: death by auto is a crime of the fourth degree]

[court_may_order: for good cause shown the court may, in accepting a plea of guilty under this subsection, order that such plea not be evidential in any civil proceeding]

2C:11-6. Aiding suicide MNEMONIC DETAILED MARKED VERSION

[aids_suicide: a person [who\} purposely aids another to commit suicide] Iguilty_2_degree: <that person> is guilty of a crime of the second degree] if [causes_attempt: (his\} <that person's> conduct catuses such suicide or an attempted suicidel, and otherwise

[guilty_4 degree: <that person is guilty> of a crime of the fourth degree]. 
5. Sample Run of NJ 2C-11 Legal Expert System ${ }^{13}$

EXPERT SYSTEMS GENERATED FROM STRUCTURAL INTERPRETATIONS OF LEGAL RULES

NEW JERSEY CODE OF CRIMINAL JUSTICE

2C:11-3. Murder.

Interpretation of Professor Layman E. Allen

person_causes?

In the situation you are analyzing is it the case that a person purposely, knowingly, recklessly, or, by driving a vehicle recklessly, causes the death of another human being? $y$

INFERRED RESULT

crimnl homicide

the person is guilty of criminal homicide

purposely_causes?

In the situation that you are analyzing is it the case that the actor purposely causes death or serious bodily injury resulting in death? $\mathrm{y}$

heat_of_passion?

In the situation that you are analyzing is it the case that the homicide is committed in the heat of passion resulting from a reasonable provocation? $n$

INFERRED RESULT

is_murder

the criminal homicide constitutes murder

knowingly_causes?

In the situation that you are analyzing is it the case that the actor knowingly causes death or serious bodily injury resulting in death? $y$

INFERRED RESULT

is murder

the criminal homicide constitutes murder

engaged_in_crime?

In the situation that you are analyzing is it the case that the criminal homicide is committed when the actor, acting either alone or with one or more other persons, is engaged in the commission of, or an attempt to commit, or flight after committing or attempting to commit robbery, sexual assault, arson, burglary, kidnapping or criminal escape? n

${ }^{13}$ This legal expert system was produced by the AUTOPROLOG program developed by Layman E. Allen and Charles $S$. Saxon with the aid of a research grant from the National Center for Automated Information Research (NCAIR). Copyright (C) 1989, Layman E. Allen, Charles S. Saxon, and NCAIR. The AUTOPRO System has been developed to demonstrate the potential of expert systems as a tool to assist law teachers and other legal professionals. It is important that users of expert systems produced by AUTOPRO understand that the legal expertise they contain has been furnished by the legal experts who developed those systems. It is the intention of the authors of AUTOPRO (1) that it be used only by qualified legal experts to produce legal expert systems embodying their expertise, and (2) that the systems they produce be used only by law students, attorneys, and other appropriately qualified persons. No report, reasons, or conclusions produced by AUTOPRO-generated expert systems should be relied upon by any users as authoritative without consulting an attorney competent to evaluate the legal effects of the information furnished. Trace of run done on July 31989 at 0:11:56. 
cmmit__recklessly?

In the situation that you are analyzing is it the case that the criminal homicide is committed recklessly? $\mathrm{n}$

aids_suicide?

In the situation that you are analyzing is it the case that a person purposely aids another to commit suicide? $\mathrm{n}$

Based on the Interpretation of Professor Laymen E. Allen of this provision and your responses given below to the questions asked:

$\begin{array}{rr}\text { QUESTIONS } & \text { RESPO } \\ \text { person_causes ? } & \mathrm{y} \\ \text { purposely_causes ? } & \mathrm{y} \\ \text { heat_of_passion ? } & \mathrm{n} \\ \text { knowingly_causes ? } & \mathrm{y} \\ \text { engaged_in_crime ? } & \mathrm{n} \\ \text { cmmit_recklessly ? } & \mathrm{n} \\ \text { aids_suicide ? } & \mathrm{n}\end{array}$

the following results can be inferred for the reasons given:

THE RESULT crimnl_homicide

CAN BE INFERRED FOR THE FOLLOWING REASON(S): person_causes.

THE RESULT -

the person is guilty of criminal homicide

CAN BE INFERRED FOR THE FOLLOWING REASON(S):

a person purposely, knowingly, recklessly, or, by driving a vehicle recklessly, causes the death of another human being.

THE RESULT -

is__murder

CAN BE INFERRED FOR THE FOLLOWING REASON(S):

person_causes,

purposely_causes, and

NOT heat_of_passion.

THE RESULT -

the criminal homicide constitutes murder

CAN BE INFERRED FOR THE FOLLOWING REASON(S):

a person purposely, knowingly, recklessly, or, by driving a vehicle recklessly, causes the death of another human being,

the actor purposely causes death or serious bodily in jury resulting in death, and

IT IS NOT SO THAT the homicide is committed in the heat of passion resulting from a reasonable provocation.

THE RESULT -

is murder

CAN BE INFERRED FOR THE FOLLOWING REASON(S):

person_causes,

knowingly_causes, and

NOT heat_of_passion. 


\section{THE RESULT -}

the criminal homicide constitutes murder

CAN BE INFERRED FOR THE FOLLOWING REASON(S):

a person purposely, knowingly, recklessly, or, by driving a vehicle recklessly, causes the death of another human being,

the actor knowingly causes death or serious bodily injury resulting in death, and IT IS NOT SO THAT the homicide is committed in the heat of passion resulting from a reasonable provocation.

On the basis of the same interpretation and the same responses none of the following results can be inferred:

\section{RESULT(S) THAT CANNOT BE INFERRED}

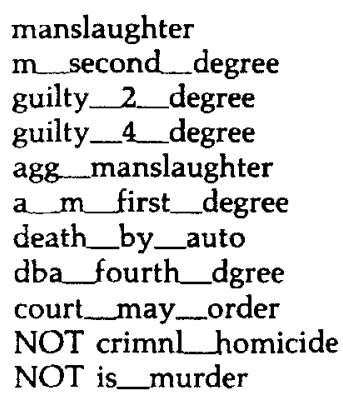

\section{Appendix B. QUINLAN Legal Expert System}

1. Clear Normalized Form of Quinlan Order for Declaratory Relief

IF

1. the responsible attending physicians conclude that there is no reasonable possibility of the patient's ever emerging from his or her present comatose condition to a cognitive, sapient state, AND

2. they conclude that the life-support apparatus now being administered to the patient should be discontinued,

THEN

3. IF

A. the guardian and family of the patient concur that such there is no such reasonable possibility of emergence and that such life-support apparatus be discontinued, THEN

B. the physicians have the LEGAL POWER to consult with the hospital 'Ethics Committee' or like body of the institution in which the patient is then hospitalized, AND

C. they MUST consult with that committee or body,

BUT OTHERWISE

D. they do not have the LEGAL POWER to consult with that committee or body, AND

E. they NEED NOT consult with that committee or body, AND

4. IF

A. they consult with that committee or body, AND

B. that consultative body agrees that there is no reasonable possibility of the patient's ever emerging from his or her present comatose condition to a cognitive, sapient state, 


\section{THEN}

C. the present life-support system MAY be withdrawn, AND

D. said action MUST be without any civil or criminal liability therefor on the part of any participant, whether guardian, physician, hospital or others,

BUT OTHERWISE,

E. the present life-support system NEED NOT be withdrawn, AND

F. said action NEED NOT be without any civil or criminal liability therefor on the part of any participant, whether guardian, physician, hospital or others,

BUT OTHERWISE,

5. they do not have the LEGAL POWER to consult with that committee or body, AND

6. they MUST NOT consult with that committee or body.

\section{Clear Mnemonic Arrow Diagram of Quinlan Order for Declaratory Relief}

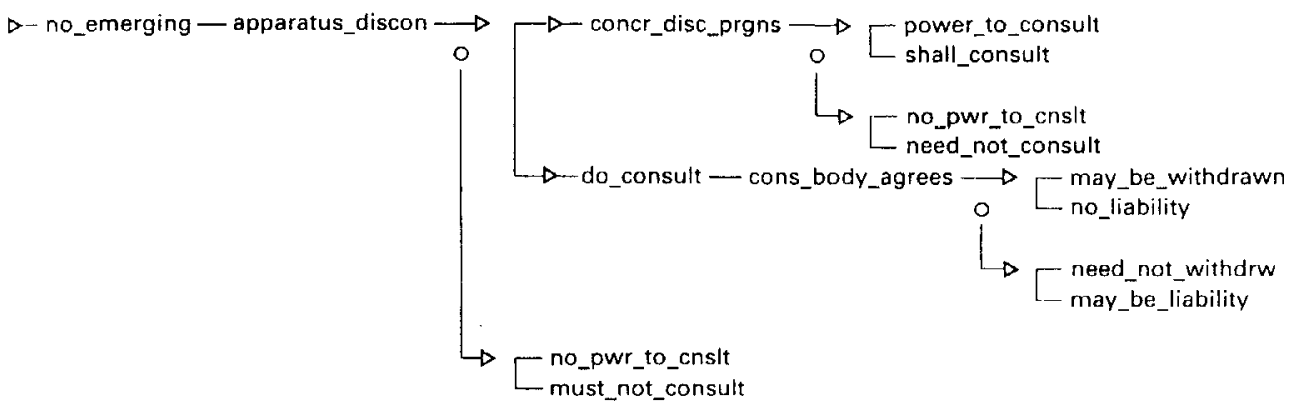

3. Input File to Generate Arrow Diagrams and Normalized Versions

with NORMALIZER and to Generate the QUINLAN LES with AUTOPRO

IN RE QUINLAN - ORDER FOR DECLARATORY RELIEF.

Interpretation of Professor Sallyanne Payton

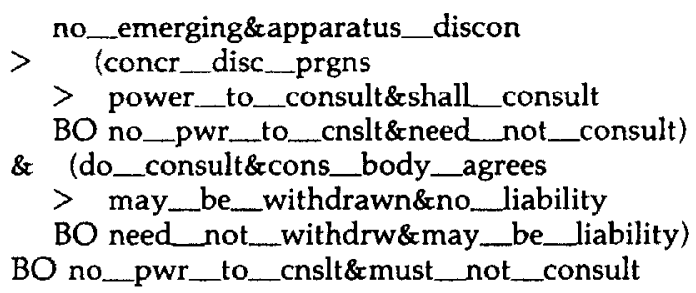

Matter of Quinlan Order for Declaratory Relief

\section{MNEMONIC DETAILED MARKED VERSION - LIST OF CONSTITUENT SENTENCES}

[family_concur: the guardian and family of the patient concur],

Ino_emerging: the responsible attending physicians conclude that there is no reasonable possibility of the patient's ever emerging from his or her present comatose condition to a cognitive, sapient state] 
[apparatus_discon: the responsible attending physicians conclude that the life-support apparatus now being administered to the patient should be discontinued],

[shall_consult: the responsible attending physicians MUST consult with that committee or body]

[do__consult: the responsible attending physicians did consult with that committee or body]

[concr_to to consult: the guardian and family of the patient concur that such consultation be undertaken],

[concr_discntinue: the guardian and family of the patient concur that such life-support apparatus be discontinued],

[concr_cnslt_disc: the guardian and family of the patient concur that such life-support apparatus be discontinued and that such consultation be undertaken],

[concr_disc__prgns: the guardian and family of the patient concur that such there is no such reasonable possibility of emergence and that such life-support apparatus be discontinued],

[concur_all_3: the guardian and family of the patient concur that such there is no such reasonable possibility of emergence, that such life-support apparatus be discontinued, and that such consultation be undertaken]

Icons_body_agrees: the hospital 'Ethics Committee' or like body of the institution agrees that there is no reasonable possibility of the patient's ever emerging from his or her present comatose condition to a cognitive, sapient state],

[may_be_withdrawn: the present life-support system MAY be withdrawn] and [must_not_withdraw: the present life-support system MUST NOT be withdrawn] and

[no__liability: said action MUST be without any civil or criminal liability therefor on the part of any participant, whether guardian, physician, hospital or others].

[must_not_consult: the responsible attending physicians MUST NOT consult with the hospital 'Ethics Committee' or like body of the institution]

[need_not_consult: the responsible attending physicians NEED NOT consult with the hospital 'Ethics Committee' or like body of the institution with that committee or body]

[need_not_withdrw: the present life-support system NEED NOT be withdrawn]

[may_be__liability: said action NEED NOT be without any civil or criminal liability therefor on the part of any participant, whether guardian, physician, hospital or others].

Lpower_to_consult: the responsible attending physicians have the LEGAL POWER to consult with the hospital 'Ethics Committee' or like body of the institution in which the patient is then hospitalized].

[no_pwr_to_cnslt: the responsible attending physicians do not have the LEGAL POWER to with the hospital 'Ethics Committee' or like body of the institution with that committee or body] 


\section{Sample run of QUINLAN Legal Expert System ${ }^{14}$}

EXPERT SYSTEMS GENERATED FROM STRUCTURAL INTERPRETATIONS OF LEGAL RULES

\section{IN RE QUINLAN - ORDER FOR DECLARATORY RELIEF \\ Interpretation of Professor Sallyanne Payton}

no_emerging?

In the situation that you are analyzing is it the case that the responsible attending physicians conclude that there is no reasonable possibility of the patient's ever emerging from his or her present comatose condition to a cognitive, sapient state? y

$$
\text { apparatus_discon? }
$$

In the situation that you are analyzing is it the case that the responsible attending physicians conclude that the life-support apparatus now being administered to the patient should be discontinued? y

concr_disc_prgns?

In the situation that you are analyzing is it the case that the guardian and family of the patient concur that such there is no such reasonable possibility of emergence and that such life-support apparatus be discontinued? y

\section{INFERRED RESULT}

power to consult

the responsible attending physicians have the LEGAL POWER to consult with the hospital "Ethics Committee" or like body of the institution in which the patient is then hospitalized

INFERRED RESULT

shall__consult

the responsible attending physicians MUST consult with that committee or body

do_consult?

In the situation that you are analyzing is it the case that the responsible attending physicians did consult with that committee or body? y

cons_body_agrees?

In the situation that you are analyzing is it the case that the hospital "Ethics Committee" or like body of the institution agrees that there is no reasonable possibility of the patient's ever emerging from his or her present comatose condition to a cognitive, sapient state? y

\section{INFERRED RESULT}

may_be_withdrawn

the present life-support system MAY be withdrawn

INFERRED RESULT

no__liability

said action must be without any civil or criminal liability therefor on the part of any participant, whether guardian, physician, hospital or others.

14 Trace of run done on July 31989 at 0:11:56. On this legal expert system, see footnote 13, supra p. 305. 
Based on the Interpretation of Professor Sallyanne Payton of this provision and your responses given below to the questions asked:

QUESTIONS

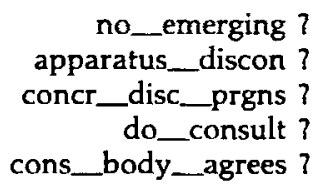

RESPONSES

y

y

y

y

y

the following results can be inferred for the reasons given:

THE RESULT power_to_consult

CAN BE INFERRED FOR THE FOLLOWING REASON(S):

no_emerging.

apparatus_discon, AND

concr_disc_prgns.

THE RESULT -

the responsible attending physicians have the LEGAL POWER to consult with the hospital "Ethics Committee" or like body of the institution in which the patient is then hospitalized

CAN BE INFERRED FOR THE FOLLOWING REASON(S):

the responsible attending physicians conclude that there is no reasonable possibility of the patient's ever emerging from his or her present comatose condition to a cognitive, sapient state,

the responsible attending physicians conclude that the life-support apparatus now being administered to the patient should be discontinued, AND

the guardian and family of the patient concur that such there is no such reasonable possibility of emergence and that such life-support apparatus be discontinued.

THE RESULT shall consult

CAN BE INFERRED FOR THE FOLLOWING REASON(S):

no_emerging,

apparatus_discon, AND

THE RESULT concr_disc_prgns.

the responsible attending physicians MUST consult with that committee or body CAN BE INFERRED FOR THE FOLLOWING REASON(S):

the responsible attending physicians conclude that there is no reasonable possibility of the patient's ever emerging from his or her present comatose condition to a cognitive, sapient state,

the responsible attending physicians conclude that the life-support apparatus now being administered to the patient should be discontinued, AND

the guardian and family of the patient concur that such there is no such reasonable possibility of emergence and that such life-support apparatus be discontinued.

THE RESULT -

may_be_withdrawn

CAN BE INFERRED FOR THE FOLLOWING REASON(S):

no_emerging,

apparatus_discon,

do_consult, AND

cons_body_agrees. 


\section{THE RESULT -}

the present life-support system MAY be withdrawn

CAN BE INFERRED FOR THE FOLLOWING REASON(S):

the responsible attending physicians conclude that there is no reasonable possibility of the patient's ever emerging from his or her present comatose condition to a cognitive, sapient state,

the responsible attending physicians conclude that the life-support apparatus now being administered to the patient should be discontinued,

the responsible attending physicians did consult with that committee or body, AND

the hospital "Ethics Committee" or like body of the institution agrees that there is no reasonable possibility of the patient's ever emerging from his or her present comatose condition to a cognitive, sapient state.

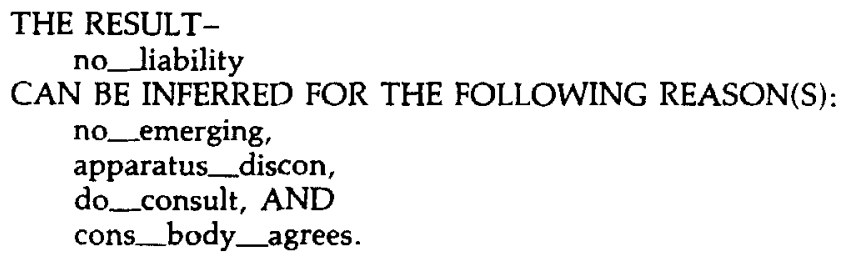

THE RESULT -

said action MUST be without any civil or criminal liability therefor on the part of any participant, whether guardian, physician, hospital or others

CAN BE INFERRED FOR THE FOLLOWING REASON(S):

the responsible attending physicians conclude that there is no reasonable possibility of the patient's ever emerging from his or her present comatose condition to a cognitive, sapient state,

the responsible attending physicians conclude that the life-support apparatus now being administered to the patient should be discontinued,

the responsible attending physicians did consult with that committee or body, AND

the hospital "Ethics Committee" or like body of the institution agrees that there is no reasonable possibility of the patient's ever emerging from his or her present comatose condition to a cognitive, sapient state.

On the basis of the same interpretation and the same responses none of the following results can be inferred:

RESULT(S) THAT CANNOT BE INFERRED

no_pwr_to_cnslt
need_not_consult
need_not_withdrw
may_be_liability
must_not_consult

Appendix C. The Synthesis of the NJ2C-11 LES with the QUINLAN LES

EXPERT SYSTEMS GENERATED FROM STRUCTURAL INTERPRETATIONS OF LEGAL RULES ${ }^{15}$

NEW JERSEY CODE OF CRIMINAL JUSTICE.

2C:11-3. Murder.

Interpretation of Professor Layman E. Allen

15 Trace of run done on July 31989 at 18:22:5. On this legal expert system, see footnote 13 , supra p. 305 . 
person—causes?

In the situation that you are analyzing is it the case that a person purposely, knowingly, recklessly, or, by driving a vehicle recklessly, CAUSES the death of another human being?

$\quad$ Select
Yes
No
Unknown
Help
Definition
Pause
Stop

When the user selected the "Definitions" option, the following appeared on the screen:

$$
\text { Press the }\langle\text { Esc }>\text { to return }
$$

In the situation that you are analyzing is it the case that a person purposely, knowingly, recklessly, or, by driving a vehicle recklessly, CAUSES* the death of another human being?

Select the word of phrase that you want defined by pressing the $<$ Right Arrow $>$ $k e y$, and when the correct word or phrase is highlighted, press the $\langle$ Return $\rangle$ key.

When the user selected the highlighted "CAUSES"," the following appeared on the screen:

Interpretation of "causes" in court opinions

(Index Name: def_causes)

IF you think that your situation is definitely like any of the situations below in which the conduct was deemed not to have caused the death of the decedent,

THEN you should choose the "No" alternative, BUT

IF you think that your situation might be deemed to be like one of them,

THEN you should move the cursor to the section that describes that situation and press the $\langle$ FIO $>$ key to explore it further.

\section{SITUATIONS $1-3$}

... (other situations not presented here)

\section{SITUATION 4}

Under certain circumstances, even if a comatose patient's death would be accelerated by withdrawal of life sustaining apparatus, the ensuing death is deemed not to be caused by the withdrawal but by existing natural causes.

Matter of Quinlan, 70 N.J, 10, 355 A.2d 647, 79 A.L.R.3d 205 (1976) certiorari denied 997 S.Ct. 319, 429 U.S. 922,50 L.Ed.2d 289.

IF you want to explore the similarity between your situation and this one in greater detail,

THEN press the $\langle$ Esc $\rangle$ key and then the $\langle\mathrm{P}\rangle$ key, and then either

(1) to access normalized representations of an expert's interpretation of the Quinlan case, enter at the system prompt: 
SHOW_CAUSE__04.INT

or

(2) to access the QUINLAN LES, enter at the system prompt:

\section{QUINLAN}

\section{SITUATIONS 5-9}

(other situations not presented here)

IF you think that your situation is definitely like any of the situations above in which the conduct was deemed not to have caused the death of the decedent,

THEN you should choose the "No" alternative, BUT

IF you think that your situation might be deemed to be like one of them,

THEN you should move the cursor to the section that describes that situation and press the $\langle$ F10 $\rangle$ key to explore it further.

When the user chose to explore SITUATION 4 further by accessing the normalized representations of the Quinlan case, the following appeared on the screen:

After you finish examining the contents of this file by scrolling through it and then press the $\langle E s c\rangle$ key to end the session with this file, you can

1) access the QUINLAN LES, by entering at the system prompt:

or QUINLAN

2) return to the NJ2C-11 LES, by entering at the system prompt:

or NJ2C-11

3) otherwise continue your research before returning to NJ2C-11.

NEW JERSEY CODE OF CRIMINAL JUSTICE

2C:11-(1-5). Criminal_Homicide, Murder, Manslaughter, Death by Auto.

Interpretation of Professor Layman E. Allen.

CONTENTS - To "scroll", use PgDn, PgUp, ArrowDown, Arrow Up, $\rightarrow$, and -

Allen Interpretation: Clear Arrow Diagrams, Outline, and Normalized Version

Clear Short Arrow Diagram of Allen Interpretation

Clear Mnemonic Arrow Diagram of Allen Interpretation

Clear Mnemonic Outline of Allen Interpretation

Clear Normalized Version of Allen Interpretation

Present Versions of New Jersey Code of Criminal Justice Provisions that deal with various forms of Criminal__Homicide

2C:11-1. Definitions

2C:11-3. Criminal_homicide_

2C:11-3. Murder

2C:11-4. Manslaughter

2C:11-5. Death by auto

\section{CLEAR MENEMONIC ARROW DIAGRAM OF QUINLAN ORDER FOR DECLARATORY RELIEF}

[for the text that appears here, see Appendix B.1.] 
CLEAR MNEMONIC OUTLINE OF QUINLAN ORDER FOR DECLARATORY RELIEF

[For the text that appears here, see Appendix B.2.]

CLEAR NORMALIZED FORM OF QUINLAN ORDER FOR DECLARATORY RELIEF

[For the text that appears here, see Appendix B.3.]

\section{PRESENT VERSION OF THE QUINLAN ORDER FOR DECLARATORY RELIEF}

In In re Quinlan, the New Jersey Supreme Court issued the order for declaratory relief that follows. Spacing is introduced to make the parts and the relationships between them more apparent.

.. we herewith declare the following affirmative relief on behalf of the plaintiff.

Upon the concurrence of the guardian and family of Karen, should the responsible attending physicians conclude

that there is no reasonable possibility of Karen's ever emerging from her present comatose condition to a cognitive, sapient state and

that the life-support apparatus now being administered to Karen should be discontinued,

they shall consult with the hospital "Ethics Committee" or like body of the institution in which Karen is then hospitalized.

If

that consultative body agrees that there is no reasonable possibility of Karen's ever emerging from her present comatose condition to a cognitive, sapient state,

that the present life-support system may be withdrawn and

said action shall be without any civil or criminal liability therefor on the part of any participant, whether guardian, physician, hospital or others.(Footnote 10) We herewith specifically so hold.

Footnote 10. The declaratory relief we here award is not intended to imply that the principles enunciated in this case might not be applicable in divers other types of terminal medical situations such as those described by Drs. Korein and Diamond, Supra, not necessarily involving the hopeless loss of cognitive or sapient life.

\section{IN THE MATTER OF KAREN QUINLAN, AN ALLEGED INCOMPETENT}

[The text of the entire opinion of the New Jersey Supreme Court in In re Quinlan, 70 N.J. 10 (1976) would appear here.]

If you are finished, then press the $\langle\mathrm{Esc}\rangle$ key to end the session with this file. Then you can

1) access the QUINLAN LES, by entering at the system prompt:

$$
\text { QUINLAN }
$$

\section{or}

2) return to the NJ2C-11 LES, by entering at the system prompt:

or

$$
\mathrm{NJ} 2 \mathrm{C}-11
$$

3) otherwise continue your research before returning to $\mathrm{NJ} 2 \mathrm{C}-11$;

When the user enters "QUINLAN" to access the QUINLAN LES, the following appears on the screen:

[For an account of a sample run of the QUINLAN LES, see Appendix B.5.] 
In the session with the QUINLAN LES the user is advised that in the situation being analyzed, removal of the respirator will not be the legal cause of the death of the patient, if that occurs. After finishing the session, when the user re-enters the NJ2C-11 LES by entering at the system prompt:

$$
\text { N]2C-11 }
$$

the NJ2C-11 LES continues its questioning. An account of the remainder of that session follows.

person_causes?

In the situation that you are analyzing is it the case that

a person purposely, knowingly, recklessly, or, by driving a

vehicle recklessly, causes the death of another human being? $\mathrm{N}$

\begin{tabular}{l}
\multicolumn{1}{c}{ Select } \\
Yes \\
No \\
Unknown \\
Help \\
Definition \\
Pause \\
Stop
\end{tabular}

aids_suicide

In the situation that you are analyzing is it the case that

a person purposely aids another to commit suicide? $\mathrm{N}$

Select

Yes

No

Unknown

Help

Definition

Pause

Stop

\section{INFERRED RESULT}

NOT crimnl homicide

IT IS NOT SO THAT

the person is guilty of criminal homicide

Based on the Interpretation of Professor Layman E. Allen of this provision and your responses given below to the questions asked:

$\begin{array}{rc}\text { QUESTIONS } & \text { RESPONSES } \\ \text { person_causes } & \\ \text { ? } & \mathrm{N} \\ \text { aids_suicide? } & \mathrm{N}\end{array}$

the following results can be inferred for the reasons given:

THE RESULT -

NOT crimnl homicide

CAN BE INFERRED FOR THE FOLLOWING REASON(S):

NOT person_causes. 


\section{THE RESULT -}

IT IS NOT SO THAT

the person is guilty of criminal homicide

CAN BE INFERRED FOR THE FOLLOWING REASON(S):

IT IS NOT SO THAT

a person purposely, knowingly, recklessly, or by driving a vehicle recklessly, causes the death of another human being.

On the basis of the same interpretation and the same responses none of the following results can be inferred:

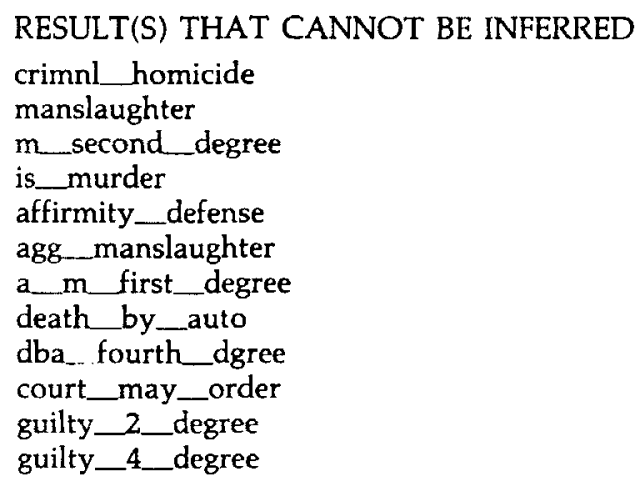

(for L. E. Allen and S. Payton)

University of Michigan

Ann Arbor

Mi 48109-1215

USA

(for Ch. S. Saxon)

Eastern Michigan University

Ypsilanti

Mi 48197

USA

\section{References}

Allen, Layman E., and Charles S. Saxon. 1985. Computer Aided Normalizing and Unpacking: Some Interesting Machine-Processable Transformations of Legal Rules. In Computer Power and Legal Reasoning. Ed. Charles Walter, 495-572. St. Paul: West Publishing Company.

- 1988a. Automatic Generation of a Legal Expert System of Model Penal Code Section 213,1 - Rape and Related Offences. (Paper presented at the 17th American Society for Information Science Mid-year Meeting, May 15-18, 1988, Ann Arbor, Mi, U.S.A.)

. 1988b. Automatic Generation of a Legal Expert System of Section 7(2) of the United Kingdom Data Protection Act 1084. Theoria 7-9: 269-315.

- 1988c. Automatic Generation of a Legal Expert System of Article 123 of the Inheritance Act of Serbia. (Paper presented at the 10th International Symposium on "Computers at the University", June 6-10, 1988, Dubrovnik/Cavtat, Yugoslavia.) 
1988d. Multiple Interpretations of the Logical Structure of Legal Rules: Impediment or Boon to Legal Expert Systems. (Paper presented at the 5th International Symposium on "Logic Programming," August 15-19, 1988, Seattle, Washington, U.S.A.)

Allen, Layman E., and Radovan Stipanovic. 1988. Automatic Generation of a Legal Expert System of the Organization for Economic Cooperation and Development's Guidelines 9 and 10 on the Protection of Privacy and Transborder Flows of Personal Data. (Paper presented at the 10th International Symposium on "Computers at the University," June 6-10, 1988, Dubrovnik/Cavtat, Yugoslavia.).

Susskind, Richard E. 1987. Expert Systems in Law. Oxford: Clarendon. 